MILENKO LONČAR

UDC: 930:94(450+398)"866/867"

TEUTA SERREQI JURIĆ

Odjel za klasičnu filologiju

Sveučilište u Zadru, Hrvatska

\title{
STILSKE VARIJACIJE PORFIROGENETOVIH IZVJEŠTAJA O POHODU SARACENA NA DALMACIJU I JUŽNU ITALIJU
}

\begin{abstract}
Povijesni izvještaj o pohodu Saracena na Dalmaciju i Bari, koji se zbio oko 866.-867. godine, donose nam tri Porfirogenetova prozna djela - Vita Bas. $(53,55)$, De them. (II, 11, 18-44) i De adm. imp. (29, 88-119). Izvješća su uklopljena u poglavlja koja govore o povijesti južne Italije i Dalmacije, a njihova se uska uzajamna povezanost objašnjava postojanjem zajedničkog izvora koji je izgubljen. Na temelju međusobne usporedbe izvješća i sustavne analize upotrebe ornatusa i ostalih specifičnosti koje karakteriziraju autorov stilski izričaj ovdje će se ukazati na stilske razlike među njima, te prezentirati kako isti izvještaj može dobiti različitu izražajnu dimenziju ovisno o generičkim značajkama djela i s time povezanom upotrebom stilskih sredstava.
\end{abstract}

\section{Uvod ${ }^{1}$}

Zanimanje za proučavanjem spisa koje nam književna tradicija donosi pod imenom bizantskog cara Konstantina VII. Porfirogeneta (913.-959.) ne jenjava već više od jednog stoljeća. Iako se u nastojanjima da se odgonetnu pitanja datacije i autorstva njima bavio čitav niz znanstvenika raznovrsnih polja, tek se nekolicina dotakla različitih stilskih razina kao vrlo bitne značajke corpusa Constantineuma. ${ }^{2}$ Otkako

${ }^{1}$ Ovaj je rad u skraćenom obliku izložen na međunarodnom znanstvenom skupu Književnost, umjetnost, kultura između dviju obala Jadrana / Letteratura, arte, cultura tra le due sponde dell' Adriatico, Zadar-Biograd na Moru, 23.-25. listopada 2014. Dijelovi ovog rada temelje se na prerađenim i dopunjenim poglavljima doktorske disertacije Teute Serreqi Jurić, "Usporedba jezično-stilskih osobitosti Porfirogenetovih djela Vita Basilii i De thematibus" (doktorska disertacija, Sveučilište u Zagrebu, 2016), 109-112, 189-249, 278-291, 339-341.

${ }^{2}$ Usporedbu stilskih osobitosti Porfirogenetovih djela Vita Basilii, De cerimoniis i De adm. imp. u kraćim crtama donosi Luigi Tartaglia ("Livelli stilistici in Costantino Porfirogenito", Jahrbuch der Österreichischen Byzantinistik 32 (1982), br. 2: 197-206), na temelju odabranih sintaktičkih i leksičkih obilježja kao i nekoliko izdvojenih primjera stilskih figura i tropa. Razmatrajući cjelokupan Konstantinov korpus, Ihor Ševčenko ("Re-reading Constantine Porphyrogenitus", u: Byzantine Diplomacy: Papers from the Twenty-Fourth Spring Symposium of Byzantine Studies, Cambridge, March 1990, ed. by Jonathan Shepard and Simon Franklin (Aldershot: Variorum, 1992), 184. i bilj. 44) ukazuje na čak pet stilskih razina u Porfirogenetovim djelima. Iako se nije dotakao stilskih 
je, uočivši da upotreba prijedloga u De adm. imp. i De cerim. obiluje barbarizmima, dok je u Vita Bas. pravilna, davne 1895. Tycho Mommsen prvi s pravom posumnjao u to da je isti čovjek napisao ova djela, ${ }^{3}$ problem različitih stilskih razina dospio je u neodvojivu vezu s pitanjem autorstva Porfirogenetovih spisa, što je u recentnijim znanstvenim istraživanjima čak dovelo do toga da je caru osporavano autorstvo većine djela. ${ }^{4}$ Iz tog bi razloga dinamiziranje proučavanja stilskog izričaja Konstantinovih djela, nekako nepravedno zanemarenog segmenta u dosadašnjim studijama o carevim spisima, svakako bilo poželjno, utoliko više što bi ne samo dalo snažan impuls u pokušaju rasvjetljavanja pitanja careva autorstva, već i pokazalo kako Konstantinov opus kao vrlo zahvalno vrelo za proučavanje bizantske grčke stilistike posjeduje i određenu književnu vrijednost, unatoč tomu što je tijekom stoljeća kod čitatelja vladao nedostatak interesa zbog njegova pretežno diplomatskodokumentarnog karaktera.

obilježja, ovdje vrijedi ukazati i na znameniti doprinos koji je poznavanju Konstanti-

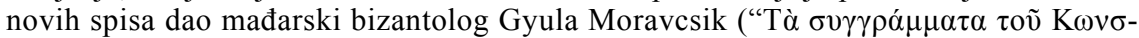

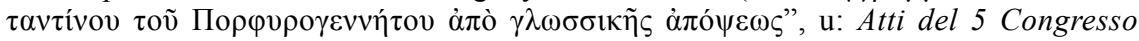
internazionale di studi bizantini, Roma 20.-26. settembre 1936. (Roma: Tipografia del Senato del dott. G. Bardi, 1939), 514-520). Proučivši s jezičnog gledišta careva četiri najveća prozna djela te govorničke spise, Moravcsik je zaključio kako su govori napisani arhaizirajućim grčkim jezikom i visokim stilom bizantske retorike, a od proznih djela najbliži su im Vita Bas. i De them., čiji je jezik manje izvještačen, no u njima se poštuju kanoni antičke gramatike i nema ni traga vulgarizmima. Za razliku od njih, De adm. imp. i De cerim. u svojem su većem dijelu pisani govornim grčkim jezikom te su prepuni vulgarizama. O jezičnim i stilskim karakteristikama dalmatinskih poglavlja De adm. imp., koje ukazuju na posebnog pisca, vidi Milenko Lončar, "Filološka analiza Porfirogenetovih vijesti o Hrvatima" (doktorska disertacija, Filozofski fakultet u Zadru Sveučilišta u Splitu, 2002), 102-105, i Milenko Lončar, "Dalmatinske etimologije Konstantina Porfirogeneta", Folia onomastica Croatica 11 (2002), 149-174. Sumaran prikaz najznačajnijih jezičnih, sintaktičkih i stilskih značajki Vita Bas. nudi Index graecitatis u Ihor Ševčenko, ed., Chronographiae quae Theophanis Continuati nomine fertur liber quo vita Basilii imperatoris amplectitur (Berlin-Boston: De Gruyter, 2011), 367-383. Detaljnu analizu sintaktičkih, leksičkih i stilskih osobitosti Vita Bas. i De them. donosi Serreqi Jurić,“Usporedba jezično-stilskih osobitosti”, 116-341.

3 Tycho Mommsen, Beiträge zu der Lehre von den griechischen Präpositionen (Berlin: Weidmannsche Buchhandlung, 1895), 449, bilj. 190 i 522-523, bilj. 41.

4 Ševčenko, "Re-reading", 176, 182, 184-185, 187, i bilj. 40, 45, 46, 49, smatra da Vita Bas. nije napisao Konstantin, već ista osoba koja je sastavila govor De imagine Edessena, argumentirajući to s oko dvadeset i pet leksičkih i frazeoloških paralela u obama djelima. U De cerim. samo je uvodno poglavlje carevo, dok su ostatak djela sastavili različiti ljudi u različito doba, a slično je i kod De them. Svečani vojni govori pokazuju samo nekoliko leksičkih sličnosti i nijednu stilsku u odnosu na ostale spise koji se atribuiraju Konstantinu. Što se tiče govora održanog prigodom prijenosa relikvija sv. Ivana Zlatoustog, i drugi su znanstvenici izrazili sumnju u Porfirogenetovo autorstvo, dok nas sam naslov govora održanog prilikom prijenosa relikvija Grgura iz Nazijanza sprječava pripisati ga Konstantinu. Ševčenko na kraju zaključuje kako se autentičnim Porfirogenetovim zapisima mogu smatrati jedino pisma razmijenjena s Teodorom iz Kizika te određeni dijelovi spisa De adm. imp. koji su pisani u prvom licu (uvodno poglavlje, pogl. 1, 4-24 i pogl. 13, 12-200). 
U želji da svojim spoznajama damo mali doprinos malobrojnom nizu radova koji se bave problematikom stilskih razina u Porfirogenetovim spisima, u ovom ćemo se radu posvetiti povijesnom izvještaju o pohodu Saracena na južnu Italiju i Dalmaciju, koji nam donose tri od Porfirogenetovih četiriju najvećih proznih djela, Vita Bas. (pogl. 53, 55), De them. (II, 11, 18-44) i De adm. imp. (pogl. 29, 88-119). Međusobnom usporedbom tih izvještaja te njihovih stilskih osobitosti kao i ostalih specifičnosti od kojih može biti satkan autorov stilski izričaj, ta će nam povijesna priča poslužiti kao zgodan primjer za ilustraciju stilskih razlika među tim djelima, pri čemu će posebna pozornost biti usmjerena na to da se pokaže kako isti izvještaj može dobiti različitu izražajnu dimenziju ovisno o generičkim značajkama djela i s time povezanom upotrebom stilskih sredstava.

\section{Faktografska pozadina priče o pohodu Saracena}

Izvješće o pohodu Saracena, povijesnom događaju koji se zbio oko 866.-867. godine, uklopljeno je u poglavlja koja govore o povijesti južne Italije i Dalmacije u prijespomenutim Konstantinovim spisima. Priča koja se u cijelosti ponavlja u Vita Bas. i De adm. imp., te samo djelomično u De them., može se raščlaniti na sljedeće epizode:

- odmetnuće slavenskih plemena - DAI pogl. 29, 54-69 = VB pogl. 52 ;

- pokrštenje Slavena - DAI pogl. 29, 70-88 = VB pogl. 54;

- pohod Saracena i bizantski protunapad - DAI pogl. 29, 88-119= $V B$ pogl. 53, $55=D T$ II, pogl. 11, 18-44;

- priča o Soldanu i Ludoviku II. - DAI pogl. 29, 119-216 =VB pogl. 56-58;

Ono što već na prvi pogled lako upada u oči jest to da je opis u Vita Bas. najduži, a u De them. sažetijeg karaktera, gdje nedostaje dio o važnoj ulozi slavenskih plemena, opširno prikazanoj u ostalim dvama djelima, te nema nastavka priče o tome kako je Soldan prevario Ludovika II. (855.-875.). Treba skrenuti pozornost i na važnu nepodudarnost u iznošenju slijeda događaja u De adm. imp. i Vita Bas. - epizoda o pokrštenju Slavena u prvome se djelu spominje prije pohoda na Dubrovnik, dok je u drugome djelu umetnuta nakon prekida arapske opsade.

Sam zapis o pohodu, koji je započeo u vrijeme cara Mihaela III. a završio za Bazilijeve vladavine, obuhvaća u Vita Bas. 53. i 55. poglavlje, u De adm. imp. pogl. 29, 88-119, dok se u De them. nalazi u II. knjizi, pogl. 11, 18-44. Gledajući s pozicije točnosti povijesnih podataka, u Konstantinovu je pripovijedanju uočljivo nekoliko pogrešaka, na što su još ranije u svojim minucioznim studijama upozorili Ferdinand Hirsch i John B. Bury. Zauzeće Barija, koje se dogodilo 841. godine, ${ }^{5}$ stavljeno

${ }^{5}$ Prema Ferdinand Hirsch, Byzantinische Studien (Leipzig: Verlag von S. Hirzel, 1876), 254-255. 
je na početak Bazilijeve vladavine, odmah nakon prekidanja saracenske opsade Dubrovnika, a zamijenjene su i dvije različite opsade Dubrovnika. Saraceni su Dubrovnik prvi put napali 847.-848., a drugi put 866.867. godine. Konstantin pripovijeda o drugoj opsadi, spominjući trojicu arapskih vođa - Soldana, Sabu i Kalfusa, ${ }^{6}$ od kojih je Soldan Mufareg ibn Salem bez sumnje bio vođa druge opsade, dok Kalfus i Saba gotovo sigurno spadaju u prvu. ${ }^{7} \mathrm{U}$ De adm. imp. javlja se i pogreška u kronologiji, gdje nalazimo iskaz da su Saraceni „vladali čitavom Lagubardi-

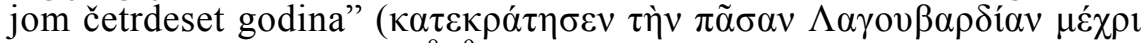

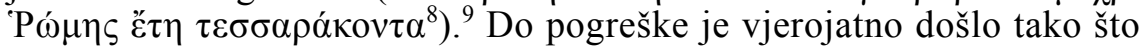
je pisac u svom izvoru iz kojeg je preuzimao podatke našao zajedno zabilježen pad Barija i prvu opsadu Dubrovnika. Pretpostavivši da se radi o istoj opsadi, onoj koju je razbio Niketa Oorifa 868. godine, pogrešno je izračunao trajanje vladavine Saracena u južnoj Italiji. O samom oslobođenju Barija govori se ukratko, samo s bizantskog stajališta, pri čemu je prešućen podatak kako ga je 871 . godine osvojio Ludovik II. te da je neko vrijeme bio u rukama stanovnika Beneventa prije nego što je prešao pod Bazilijevu vlast krajem $876 .{ }^{10}$

${ }^{6}$ Jenkins u Constantine Porphyrogenitus, De administrando imperio. A Commentary, ed. by Romilly J. H. Jenkins et al. (London: University of London, 1962), 103, donosi podatke o saracenskim vođama: Saba je vladao Tarantom oko 839., Kalfus je osvojio Bari 841., a Soldan je njime vladao 861.-871.

${ }^{7}$ Hirsch, Byzantinische Studien, 255. Gavro Manojlović, "Jadransko pomorje IX. stoljeća u svjetlu istočno-rimske (bizantinske) povijesti”, Rad JAZU 150 (1902), 65, drži da treba odvojiti napad na Budvu, Rose i Kotor, koji se zbio 841., od onoga na Dubrovnik iz vremena Bazilija I.; usp. i Mladen Švab, ur., Nikola pl. Tomašić, prev., Konstantin Porfirogenet. O upravljanju carstvom (Zagreb: August Cesarec, 1994), 69, bilj. 253. Tako i Ferdo Šišić, Povijest Hrvata u vrijeme narodnih vladara (Zagreb: Nakladni zavod Matice hrvatske, 1990; pretisak izdanja iz 1925.), 329, 346, stavlja Kalfusov napad na Budvu, Rose i Kotor u 841. godinu, a na Dubrovnik u 866. Božidar Ferjančić, ur., Vizantiski izvori za istoriju naroda Jugoslavije, tom II (Beograd: Naučna knjiga, 1959), 17-18, bilj. 29, uvjerljivo argumentira kako treba odijeliti napad na Dubrovnik od onoga na Bari. Pogrešno povezivanje omogućeno je činjenicom što su grad opsjedali upravo Arapi iz Barija kojim su vladali od 841. do 871. Lujo Margetić, "Bilješke u vezi s nastankom hrvatske države u 9. stoljeću", u: Etnogeneza Hrvata, ur. Neven Budak (Zagreb: Nakladni zavod Matice Hrvatske i Zavod za hrvatsku povijest Filozofskog fakulteta Sveučilišta u Zagrebu, 1995), 144-145, smješta arapske vođe Sabu i Kalfusa u peto desetljeće 9. stoljeća, te smatra kako je Porfirogenet u carskom arhivu našao vijest o arapskom napadu na Dalmaciju koji se zbio u vrijeme neposredno pred dolazak na vlast cara Mihaela III. te je, želeći ovog cara prikazati u što lošijem svjetlu a istovremeno svom djedu Baziliju pripisati dobre zasluge, povezao s vladavinom svoga djeda i s ponovnim osvajanjem Barija.

${ }^{8}$ De adm. imp., 29, 102-103.

9 Jenkins u Porphyrogenitus, Commentary, 104: „'Forty years' should be 'thirty years' (841.-871.); $c f$. John the Deacon, 119: 'quam... civitatem... Saracenorum gens per annos circiter triginta tenuerunt."'

${ }^{10}$ John B. Bury, "Rasprava De administrando imperio", prev. Šandor Lochmer, Vjestnik Kraljevskog hrvatsko-slavonsko-dalmatinskog arkiva 10 (1908), 118.; usp. i Ferjančić, Vizantiski izvori, 17-18, bilj. 29. O ostalim pogreškama u Porfirogenetovu pripovijedanju vidi Hirsch, Byzantinische Studien, 257-259. 
Iz međusobne usporedbe izvješća izranja njihova snažna međuovisnost, na temelju čega su John B. Bury i Gyula Moravcsik zaključili kako sva tri potječu nezavisno iz istog vrela. ${ }^{11} \mathrm{Kad}$ se sučele ovi zapisi, moguće je uočiti nekolicinu podudarnosti i razlika među njima, koje ćemo radi bolje preglednosti navesti onim redoslijedom u kojem se pojavljuju u samom tekstu:

- na početku izvještaja sva su tri spisa podudarna oko toga da su Saraceni doplovili s brodovljem od trideset i šest lađa pod zapovjedništvom Soldana, Sabe i Kalfusa, te da su opustošili različite gradove u Dalmaciji, Budvu, Rose (ili Risan) ${ }^{12}$ i Kotor; $^{13}$

- $\mathrm{u}$ De them. stoji da su Saraceni doplovili za vrijeme vladavine

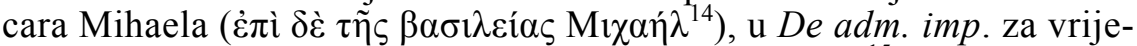

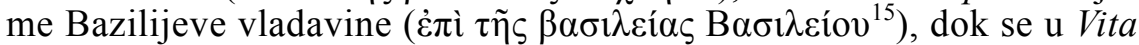
Bas. ne spominje u vrijeme čije je vladavine to bilo, no može se zaključiti da je riječ o onoj cara Mihaela III. jer se u nastavku istog, 53. poglavlja, govori kako je, dok su dubrovački poslanici još uvijek bili na putu prema Konstantinopolu, upravo preminuo „nevaljali car” odnosno Mihael; ${ }^{16}$

- De adm. imp. daje točan podatak o kronološkom trajanju opsade

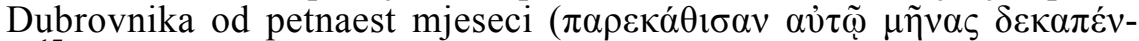
$\left.\tau \varepsilon^{17}\right)$, dok u De them. i Vita Bas. nalazimo isti, općeniti izraz „opsjedali

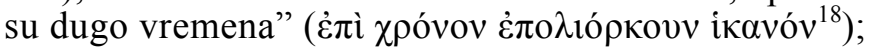

- u De them. i Vita Bas. stoji da je u vrijeme dolaska dubrovačkog poslanstva u Konstantinopol Bazilije upravo sjeo na prijestolje, ${ }^{19}$ dok u

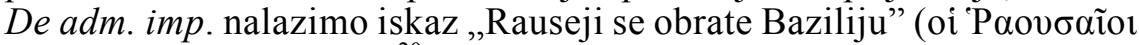

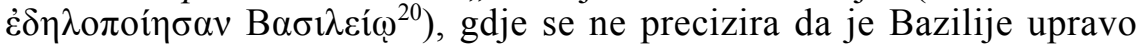
tada došao na vlast;

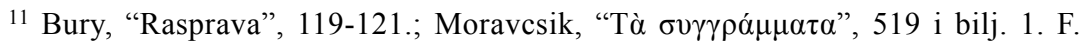
Dvornik u Porphyrogenitus, Commentary, 102, smatra kako ne postoji čvrst dokaz da sve tri verzije ne potječu od istog autora i iz istog izvora. Pertusi je u Costantino Porfirogenito, De thematibus, introduzione, testo critico, commento a cura di Andrea Pertusi (Città del Vaticano: Biblioteca Apostolica Vaticana, 1952), 44-47, pokušao dokazati da je verzija u De them. kasnija od ostalih dviju te da potječe od drugog autora.

12 Rose su mjesto u Crnoj Gori, smješteno na poluotoku Luštici na samom ulazu u Bokokotorski zaljev. Njega podrazumijeva Šišić, Povijest Hrvata, 329, 728. U Švab, Tomašić, Konstantin Porfirogenet, 69, u prijevodu stoji „Rozu”, a u bilj. 254 „,možda Porto Rose”. Jenkins u Porphyrogenitus, Commentary, 104: „Porto Rosa or, less probably, Risano”. Ferjančić, Vizantiski izvori, 17, prevodi „Risan”. Ševčenko, Chronographiae, 353, u kazalu: „nunc Risan, urbs Dalmatiae maritima ad hibernum solis ortum Ragusae (Dubrovnik) iacens".

${ }^{13}$ De them., II, 11, 18-22; Vita Bas., 53, 2-8; De adm. imp., 29, 88-93.

${ }^{14}$ De them., II, 11, 18.

${ }^{15}$ De adm. imp., 29, 88-89.

16 Vita Bas., 53, 20-21.

${ }^{17}$ De adm. imp., 29, 93-94.

18 Vita Bas., 53, 10-11; De them., II, 11, 23.

${ }^{19}$ De them., II, 11, 25-26; Vita Bas., 53, 18-23.

${ }^{20}$ De adm. imp., 29, 94-95. 
- u Vita Bas. i De adm. imp. navodi se ime zapovjednika bizantske mornarice Nikete Oorife ${ }^{21}$ koji je poslan od Bazilija dalmatinskim plemenima u pomoć sa sto lađa; ${ }^{22} \mathrm{u}$ De them. izostavljeno je Niketino ime kao i broj lađa, umjesto čega stoji „,poduzetni zapovjednik” ( $\delta \rho \alpha \sigma \tau \mid \rho t o \varsigma$

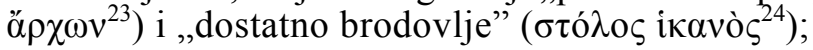

- u De them. i Vita Bas. nedostaje (pogrešan) kronološki podatak o četrdeset godina koliko je južna Italija bila pod Soldanom, što se spominje u De adm. imp.: ,zavlada (sc. Soldan) čitavom Lagubardijom sve

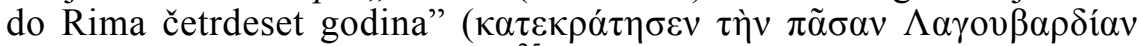

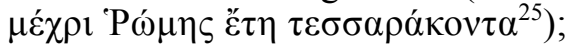

- u De them. i Vita Bas. spominje se brojka od stotinu i pedeset gradova koje su Saraceni razorili, ${ }^{26}$ čega nema u De adm. imp.;

- sva tri spisa donose vijest da se Bazilije, nakon što je čuo da su Arapi osvojili Bari i opustošili jug Italije, obratio za pomoć franačkom kralju Ludoviku II. i papi ${ }^{27}$ te da su se obojica odazvali pozivu i zajedničkim snagama natrag zadobili Bari, ${ }^{28}$ pri čemu se samo u De them. navodi kako je car na jug Italije sa sto lađa poslao i konjaničku vojsku

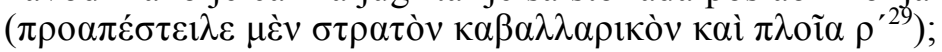

- u De adm. imp. i Vita Bas. stoji da su u borbi protiv Arapa u sklopu bizantske vojske sudjelovala i dalmatinska plemena (u De adm. imp. nabrojana su njihova imena, dok u Vita Bas. stoji ,prijespomenuta slavenska područja", čiji su stanovnici navedeni u prethodnom, 54. poglavlju u kojem se govori o pokrštenju slavenskih plemena) te da su ih na italsko tlo prevezli stanovnici Raguze na svojim lađama; ${ }^{30} \mathrm{u}$ De them . ti su podaci izostavljeni;

- u De them. i De adm. imp. navedeno je ime franačkog kralja Ludovika koji je arapskog vođu Soldana odveo u Kapuu, ${ }^{31}$ dok je u Vita Bas. njegovo ime ispušteno, umjesto čega stoji samo „franački kralj” (ó $\left.\dot{\rho} \eta \dot{\xi} \Phi \rho \alpha \gamma \gamma \dot{i} \alpha \varsigma^{32}\right)^{33}$

${ }^{21} \mathrm{O}$ tom bizantskom dužnosniku, koji je neko vrijeme bio eparh Konstantinopola i zapovjednik bizantske mornarice, vidi John B. Bury, A History of the Eastern Roman Empire (London: Macmillan and co., 1912), 143-144, bilj. 7 i 290, bilj. 1. Usp. i Porphyrogenitus, Commentary, 104.

${ }^{22}$ Vita Bas., 53, 28-32; De adm. imp., 29, 97-98.

${ }^{23}$ De them., II, 11, 27-28.

${ }^{24}$ De them., II, 11, 27.

${ }^{25}$ De adm. imp., 29, 102-103.

${ }^{26}$ Vita Bas., 55, 5-6; De them., II, 11, 33-34.

${ }^{27}$ Prema Šišić, Povijest Hrvata, 349, po godinama vladanja to bi trebao biti Hadrijan II. (867.-872.).

${ }^{28}$ De them., II, 11, 34-40; Vita Bas., 55, 19-31; De adm. imp., 29, 103-112.

${ }^{29}$ De them., II, 11, 35-36.

${ }^{30}$ Vita Bas., 55, 23-26; De adm. imp., 29, 108-111, 113-115.

${ }^{31}$ De them., II, 11, 41-42; De adm. imp., 29, 117-119.

32 Vita Bas., 55, 32-33.

${ }^{33}$ Od sličnosti i razlika među tim trima izvješćima, Bury u "Rasprava", 119, navodi kako Vita Bas. i De them. bilježe da je dubrovačko poslanstvo bilo poslano Mihaelu III., ali su poslanici na prijestolju zatekli Bazilija, dok De adm. imp. samo kaže oi 


\section{De them.}

'E$\pi \grave{i} \delta \grave{\varepsilon} \tau \tilde{\eta} \varsigma \beta \alpha \sigma \imath \lambda \varepsilon i ́ \alpha$

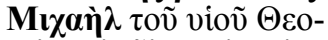

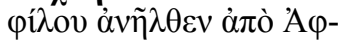

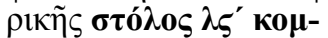

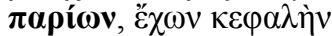

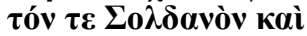

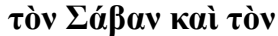

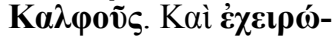

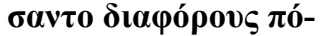

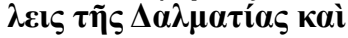

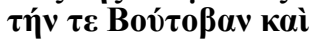

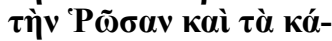
$\tau \omega \Delta \varepsilon \kappa o ́ \tau \varepsilon \rho \alpha$.

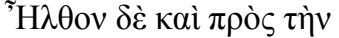

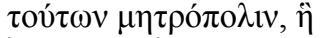

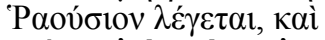

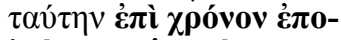
$\lambda$ lópкоvv ikavóv.
}

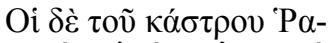

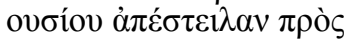

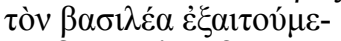

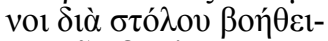

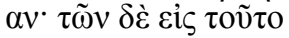

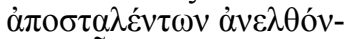

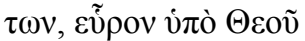

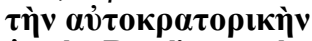

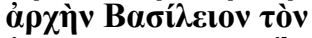

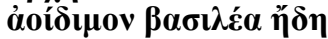

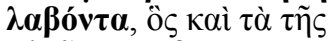

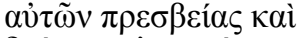

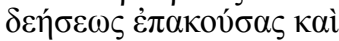

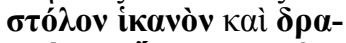

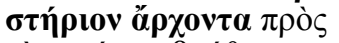

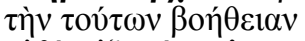

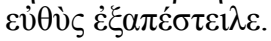

De adm. imp.

Vita Bas.

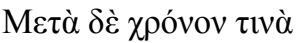
$\dot{\varepsilon} \pi \grave{i} \tau \tilde{\eta} \varsigma \beta \alpha \sigma \imath \lambda \varepsilon i ́ \alpha \varsigma$ Ba-

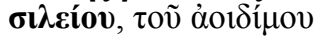

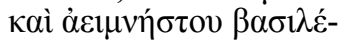

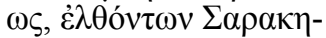

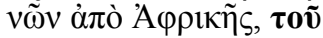

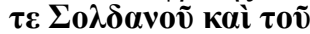

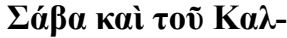

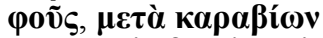
$\lambda \xi^{\prime}, \kappa \alpha \tau \varepsilon \dot{\varepsilon} \lambda \alpha \beta$ ov غ่v $\Delta \varepsilon \lambda-$

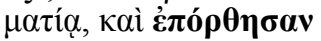

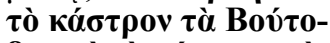

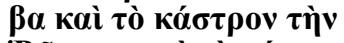

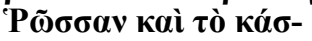

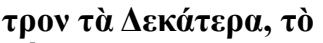

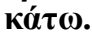

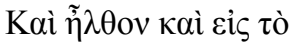

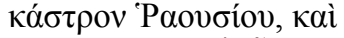
$\pi \alpha \rho \varepsilon \kappa \alpha ́ \theta t \sigma \alpha \nu \alpha \hat{\tau} \tilde{\omega} \boldsymbol{\mu} \tilde{\eta}-$ $\operatorname{v\alpha \varsigma } \delta \varepsilon \kappa \alpha \pi \varepsilon ́ v \tau \varepsilon$.

Tó $\varepsilon \varepsilon \beta 1 \alpha \sigma \theta \varepsilon \dot{v} \tau \varepsilon \varsigma$ oi ${ }^{\mathrm{P} \alpha} \alpha$

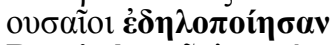

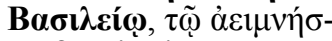
$\tau \omega \beta \alpha \sigma \imath \lambda \varepsilon \tilde{\imath}{ }^{`} \mathrm{P} \omega \mu \alpha i \omega v$,

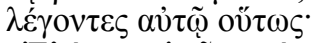

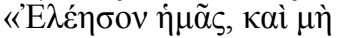

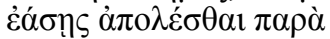
$\tau \tilde{\omega} \nu \alpha \dot{\alpha} \rho \vee \eta \tau \tilde{\omega} \nu \tau o \tilde{v} \mathrm{X} \rho 1 \sigma-$

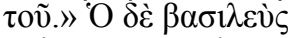
$\sigma \pi \lambda \alpha \gamma \chi v 1 \sigma \theta \varepsilon i \varsigma \varsigma \alpha \dot{\alpha} \varepsilon \dot{\sigma} \sigma \varepsilon 1-$

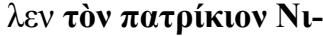

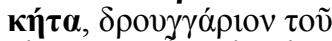

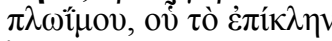

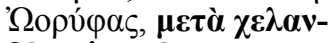

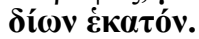

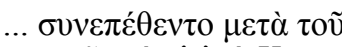

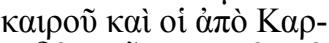

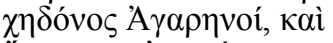

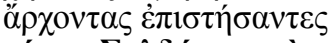

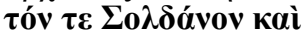
$\Sigma \alpha ́ \mu \beta \alpha v$ Kà̀ $\tau o ̀ v ~ K \alpha \lambda-$

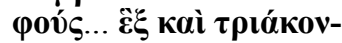
$\tau \alpha \pi \lambda \circ i ́ \omega v \pi 0 \lambda \varepsilon \mu \iota \kappa \tilde{\omega} v$

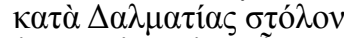

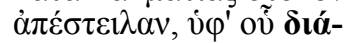

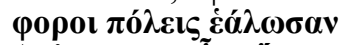
$\Delta \alpha \lambda \mu \alpha \tau \tilde{\omega} v$, oíov

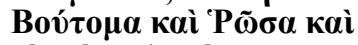

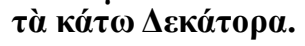

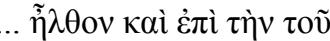

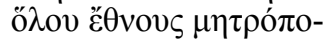

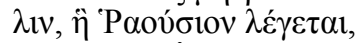

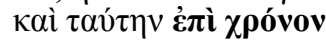

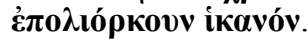

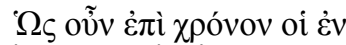

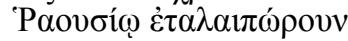

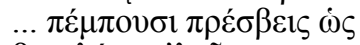
$\beta \alpha \sigma 1 \lambda \varepsilon \dot{\varepsilon} \alpha \ldots \dot{\varepsilon} \lambda \varepsilon \tilde{\eta} \sigma \alpha 1$ $\pi \alpha \rho \alpha \kappa \alpha \lambda \sigma \tilde{v} \nu \tau \varepsilon \zeta \kappa \alpha i ̀$ $\dot{\varepsilon} \pi \alpha \mu \tilde{v} v \alpha 1 . . .00 ̋ \pi \omega \delta \dot{\varepsilon} \tau \tilde{\omega} \nu$

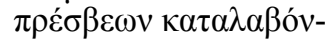
$\tau \omega \nu \tau \eta ̀ v ~ \beta \alpha \sigma 1 \lambda \varepsilon v ́ 0 v \sigma \alpha \nu . .$.

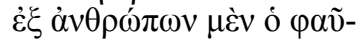

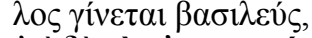

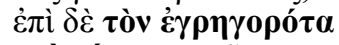

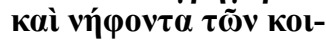

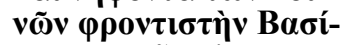

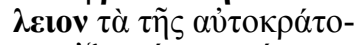

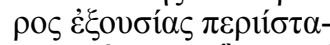

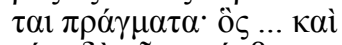

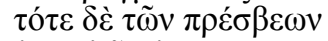

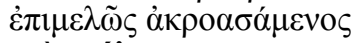

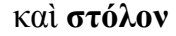

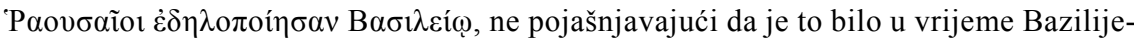
va dolaska na vlast, te da De adm. imp. daje točno trajanje opsade Dubrovnika od pet-

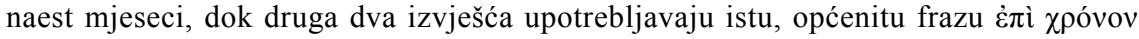

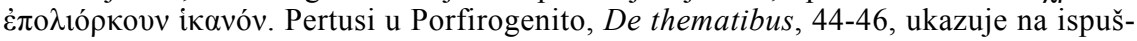
tanje imena Nikete Oorife u De them. te na podudarnosti između tog spisa i Vita Bas., poput izostanka podatka o četrdesetogodišnjoj vladavini Saracena (koji zatječemo u

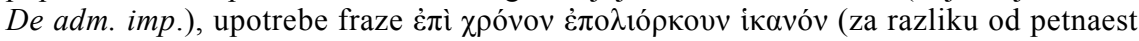
mjeseci u De adm. imp.) te obavijesti o stotinu i pedeset gradova koje su Saraceni osvojili (čega nema u De adm. imp.).
} 


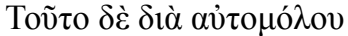

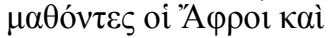

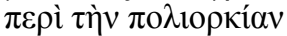
$\dot{\alpha} \pi \rho \alpha \kappa \tau \eta \dot{\sigma} \sigma \alpha \tau \varepsilon \zeta, \mu \tilde{\alpha} \lambda \lambda \sigma \nu$

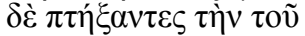

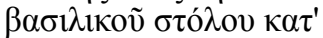
$\alpha \cup ̉ \tau \tilde{\omega} v \pi \alpha \rho o v \sigma i ́ \alpha v, \grave{\alpha} v \varepsilon-$

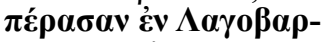

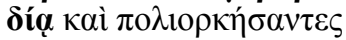

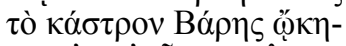
$\sigma \alpha \nu \dot{\varepsilon} \nu \alpha \hat{\varphi} \tau \tilde{\varphi}, \pi \alpha \rho \alpha \lambda \alpha-$

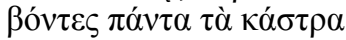

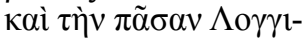

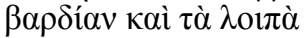

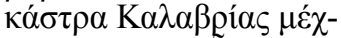

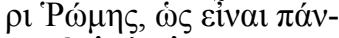

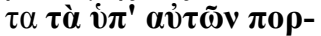

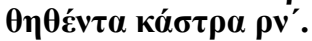

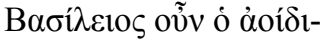

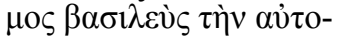

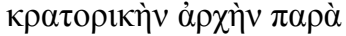

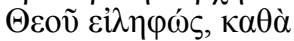
$\pi \rho о \varepsilon i ́ p \eta \tau \alpha l, ~ \kappa \alpha i ̀ ~ \tau \alpha \tilde{\tau} \tau \alpha$

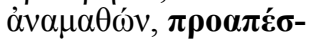

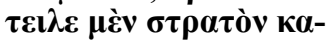

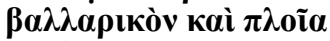
$\rho^{\prime}$, हैy

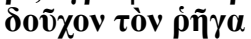

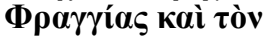

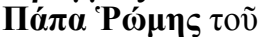

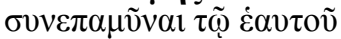

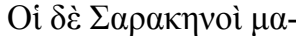

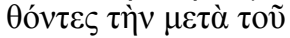

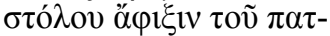

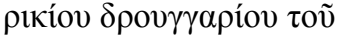
$\pi \lambda \omega \ddot{\mu} \mu \mathrm{ov}, \ddot{\varepsilon} \varphi v \gamma \circ \mathrm{v} \kappa \alpha \tau \alpha-$

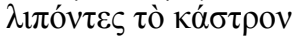

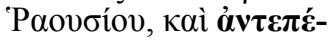

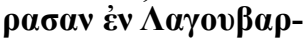

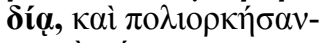

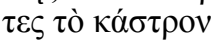

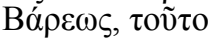
غ̇лó $\rho \theta \eta \sigma \alpha \nu$. Tó $\tau \varepsilon$ ó

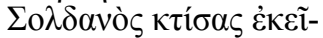
$\sigma \varepsilon \pi \alpha \lambda \alpha ́ \tau 1 \alpha, \kappa \alpha \tau \varepsilon \kappa \rho \alpha ́ \tau \eta-$

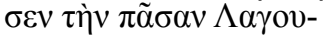

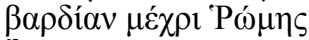

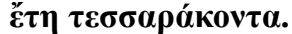

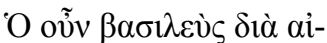
$\tau i ́ \alpha v \tau \alpha v ́ \tau \eta v$ à $\pi \varepsilon ́ \sigma \tau \varepsilon เ \lambda \varepsilon v$

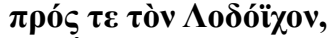

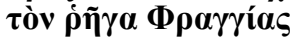

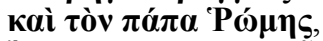

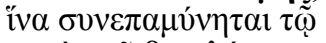

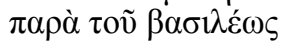
$\dot{\alpha} \pi 0 \sigma \tau \alpha \lambda \varepsilon \varepsilon^{\prime} \nu \tau 1 \sigma \tau \rho \alpha \tau \tilde{\omega}$.

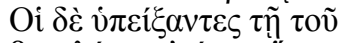

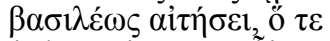

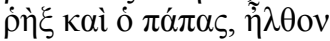

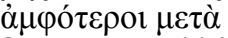
$\delta v v \alpha ́ \mu \varepsilon \omega \varsigma \pi \mathrm{o} \lambda \lambda \tilde{\eta} \varsigma, \kappa \alpha i ̀$

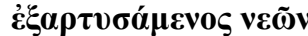

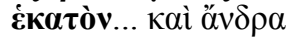

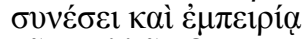
$\tau \tilde{\omega} \nu \pi \mathrm{o} \lambda \lambda \tilde{\omega} \nu \delta 1 \alpha \varphi \varepsilon ́ \rho \circ \tau \tau \alpha$

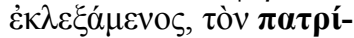

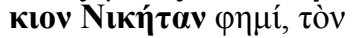

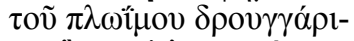
ov, òs $\kappa \alpha \tau^{\prime}$ غ̇ $\pi \omega v v \mu i ́ \alpha v$

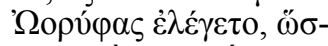

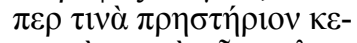

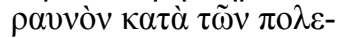

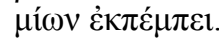

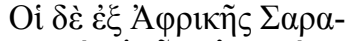

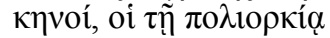
$\tau \tilde{\eta} \varsigma \pi \delta ́ \lambda \varepsilon \omega \varsigma \pi \rho о \sigma \kappa \alpha \theta \dot{\eta}-$

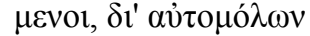

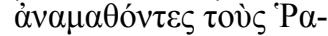

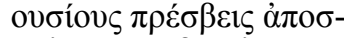

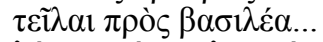

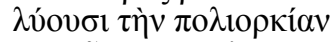

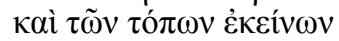

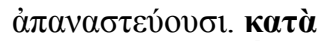

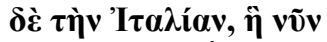

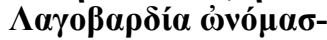

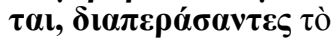

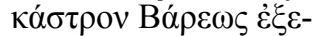
$\pi$ ó $\theta \eta \sigma \alpha v, \pi \tilde{\alpha} \sigma \alpha \nu \tau \eta े \nu$

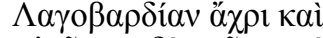
$\alpha u ̛ \tau \tilde{\eta} \varsigma \sigma \chi \varepsilon \delta$ òv $\tau \tilde{\eta} \varsigma \pi 0 \tau \grave{\varepsilon}$ $\mu \varepsilon \gamma \alpha \lambda \circ \delta$ ó

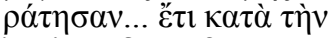

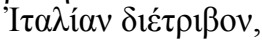

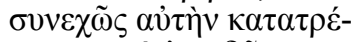

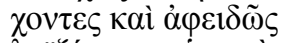

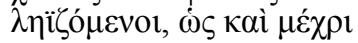

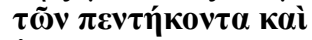

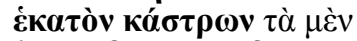

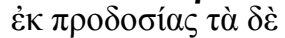

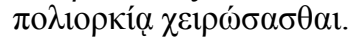

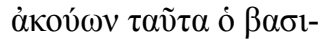

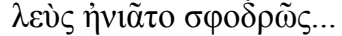

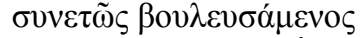

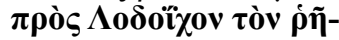

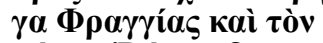

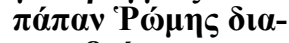
$\pi \rho \varepsilon \sigma \beta \varepsilon v ́ \varepsilon \tau \alpha \iota$

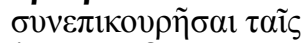

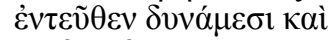

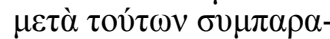

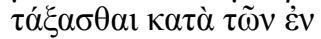

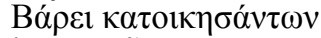
А $\gamma \alpha \rho \eta v \tilde{\nu} v, \boldsymbol{\kappa} \varepsilon \lambda \varepsilon v \boldsymbol{\sigma} \boldsymbol{\alpha} \varsigma$ 
$\sigma \tau \rho \alpha \tau \tilde{\omega}$. Oi $\delta \varepsilon \grave{~ v i \pi \varepsilon i ́-~}$

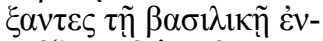

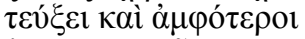

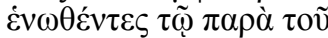
$\beta \alpha \sigma \lambda \lambda \varepsilon \dot{\varepsilon} \omega \varsigma \alpha \dot{\alpha} \pi 0 \sigma \tau \alpha \lambda \dot{\varepsilon} \nu \tau \imath$ $\sigma \tau \rho \alpha \tau \tilde{\omega} \kappa \alpha \beta \alpha \lambda \lambda \alpha \rho 1 \kappa \tilde{\omega}$ $\kappa \alpha i ̀ ~ \pi \lambda \omega \hat{i} \mu \omega, \kappa \alpha \tau \varepsilon \pi \mathrm{o} \lambda \dot{\varepsilon}-$

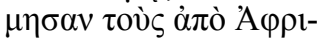

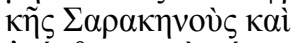

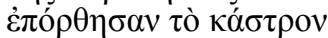

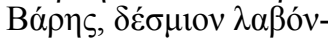

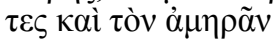
$\Sigma o \lambda \delta \alpha v o ́ v \cdot$ ôv kà àva$\lambda \alpha \beta o ́ \mu \varepsilon v o \varsigma \mu \varepsilon \tau \dot{\alpha} \tau \tilde{\omega} v$

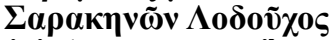

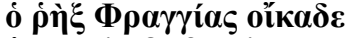

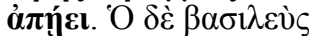
$\kappa \alpha \tau \dot{\varepsilon} \sigma \chi \varepsilon \tau \eta े \nu \pi \tilde{\alpha} \sigma \alpha \nu$

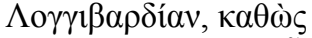

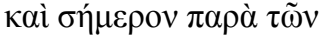

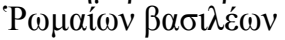

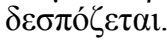

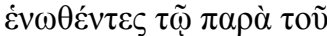

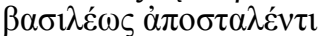
$\sigma \tau \rho \alpha \tau \tilde{\alpha}$ ớ $\boldsymbol{\alpha} \tau \tilde{\omega} \mathbf{X \rho \omega -}$

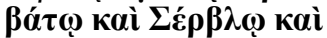

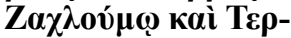

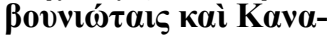

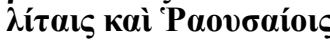
$\mu \varepsilon \tau \hat{\alpha} \pi \alpha ́ v \tau \omega v \tau \tilde{\omega} v$ à $\pi \grave{o}$

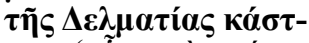
$\rho \omega v$ (oṽนol $\gamma \grave{\alpha} \rho \pi \alpha ́ v \tau \varepsilon \varsigma$ $\beta \alpha \sigma \imath \lambda \iota \kappa \tilde{~} \kappa \varepsilon \lambda \varepsilon v ́ \sigma \varepsilon 1 \pi \alpha-$

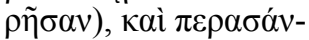
$\tau \omega v$ Év $\Lambda \alpha \gamma o v \beta \alpha \rho \delta i ́ \alpha$,

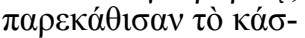

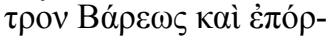

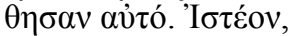

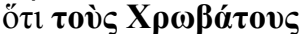

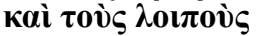

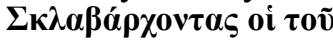

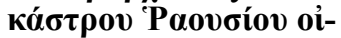

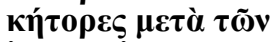

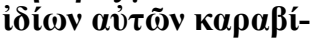

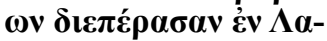

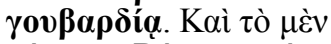

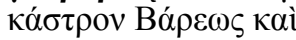

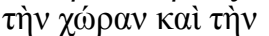
$\alpha i \chi \mu \alpha \lambda \omega \sigma i \alpha \nu \pi \tilde{\alpha} \sigma \alpha \nu$

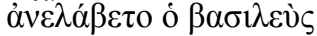
$\tau \tilde{\omega} v{ }^{\mathrm{P}} \omega \mu \alpha i ́ \omega v, \boldsymbol{\tau o ̀ v} \boldsymbol{\delta} \dot{\varepsilon}$

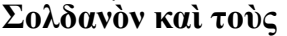

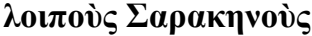

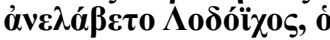

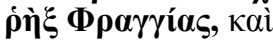
$\dot{\alpha} \pi \eta ́ \gamma \alpha \gamma \varepsilon v \alpha \hat{v} \tau$ où $\zeta \dot{\varepsilon} v \tau \tilde{\omega}$

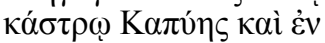

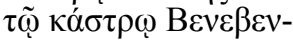
ઈoṽ.

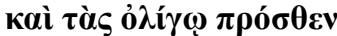
$\mu v \eta \mu 0 v \varepsilon v \theta \varepsilon i ́ \sigma \alpha \varsigma \chi \omega ́ \rho \alpha \varsigma$ $\tau \tilde{\omega} \nu \Sigma \kappa \lambda \alpha \beta \eta v \tilde{\omega} v \sigma v v-$ $\varepsilon \pi \imath \lambda \alpha \beta \varepsilon ́ \sigma \theta \alpha \iota ~ \tau 0 \tilde{~}$

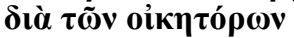

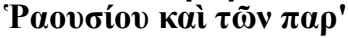

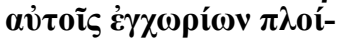

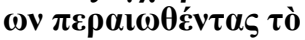
$\pi \varepsilon \dot{\varepsilon} \lambda \alpha \gamma 0 \varsigma \Delta \alpha \lambda \mu \alpha \tau \tilde{\omega} v . \tilde{\omega} v$

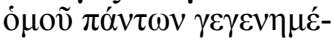

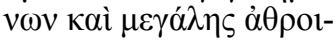

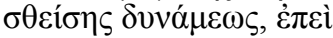

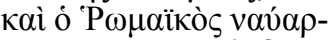

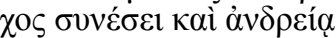

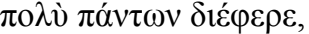

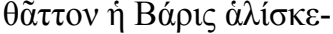

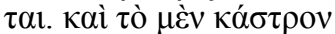

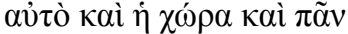

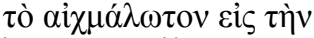
'Р

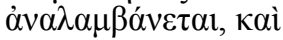

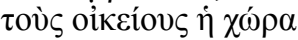

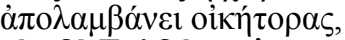

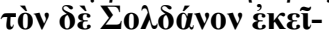

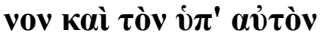
$\lambda \alpha \grave{v} v \tau \tilde{\omega} v$ A $\gamma \alpha \rho \eta v \tilde{\omega} v \dot{o}$

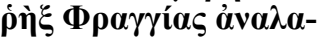

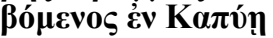

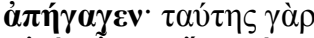
$\alpha$ vò $\pi \rho \circ \sigma \varepsilon ́ \tau \imath ~ B \varepsilon v \varepsilon \beta \varepsilon v \delta o \tilde{.}$.

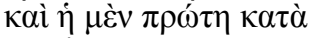

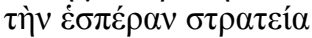

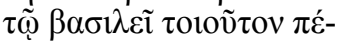

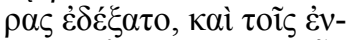
$\tau \varepsilon \tilde{v} \theta \varepsilon v \lambda \alpha \varphi v ́ \rho 01 \varsigma \kappa \alpha i ̀ ~ \tau \tilde{~}$

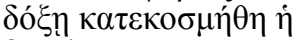
$\beta \alpha \sigma \imath \lambda \varepsilon v ́ o v \sigma \alpha$.

\section{Stilske varijacije izvještaja u Vita Bas., De adm. imp. i De them.}

U nastavku rada razmotrit ćemo na koji je način taj nesumnjivo isti predložak autor (ili autori?) stilski uklopio u svojim trima djelima. Kako bismo izvještaje lakše usporedili, priču o arapskom pohodu podijelili smo na nekoliko zaokruženih cjelina.

Napad na Budvu, Rose, Kotor i Dubrovnik. Prva bi cjelina govorila o tome kako su Arapi krenuli iz Afrike s brodovljem od trideset i šest lađa pod zapovjedništvom Soldana, Sabe i Kalfusa, pokorili gradove na dalmatinskoj obali Budvu, Rose i Kotor te došli do Dubrovnika koji su opsjedali neko vrijeme. Ovaj je zapis u De them. i De adm. imp. dosta sažeto iznesen, gdje se navode samo osnovne informacije, tj. broj 
lađa i zapovjednici arapske mornarice, pokoreni dalmatinski gradovi te trajanje opsade Dubrovnika:

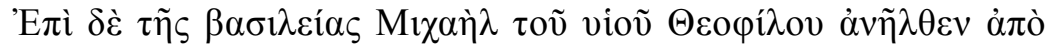

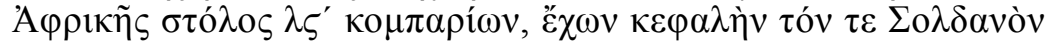

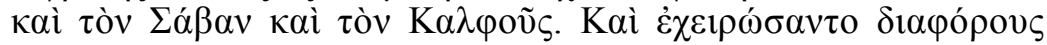

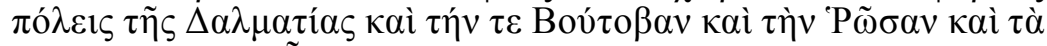

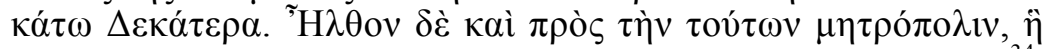

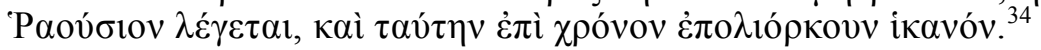

„U vrijeme vladavine Mihaela, Teofilova sina, pristigne iz Afrike brodovlje od trideset i šest komparija sa Soldanom, Sabom i Kalfusom na čelu. I pokore različite dalmatinske gradove, Butovu, Rosu i donja Dekatera. Dođoše i do njihova glavnoga grada, koji se zove Rausij, i podsjedahu ga dugo vremena." 35

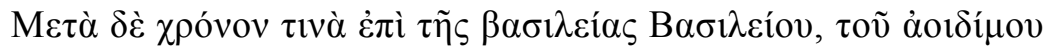

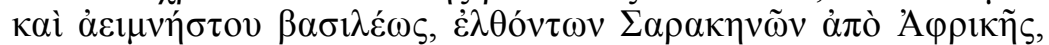

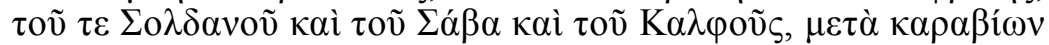

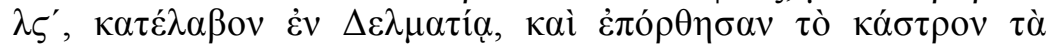

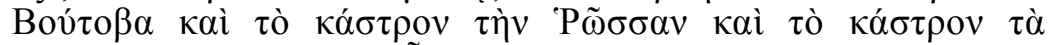

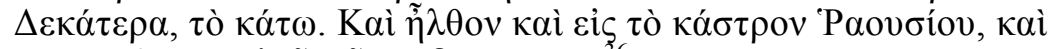

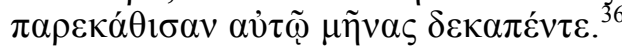

„Nakon nekog vremena, za vladavine Bazilija, slavnoga cara vječnoga spomena, pođu Sarakeni iz Afrike, Soldan, Saba i Kalfus, s trideset i šest korablja, stignu u Delmatiju i razore kastrume Butovu, Rosu i donja Dekatera. I dođu do kastruma Rausija, i držahu ga pod opsadom petnaest mjeseci."

Od stilskih ukrasa na obama mjestima uočavamo samo figure iskaza; u De them. prisutni su jedan hiperbat ${ }^{37}$ i dvije zeugme, ${ }^{38}$ a u $D e$ adm. imp. jedan homeoarkt, ${ }^{39}$ jedna zeugma ${ }^{40}$ te jedan primjer etimološke figure koji bi istovremeno bio i paronomazija. ${ }^{41}$

${ }^{34}$ De them., II, 11, 18-23.

${ }^{35}$ Prijevod Teuta Serreqi Jurić i Milenko Lončar.

${ }^{36}$ De adm. imp. 29, 88-94.

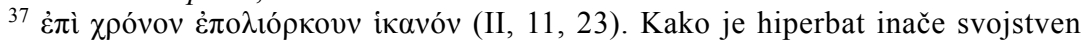
prirodi grčkog jezika (o tome vidi John D. Denniston, Greek Prose Style (Oxford: Clarendon Press, 1952) 47-59), kod ove smo stilske figure u obzir uzeli ona mjesta na kojima smo procijenili da je autor ciljano razdvojio dvije međusobno sintaktički bliske riječi, kako bi time polučio poseban izražajni efekt, umetanjem glagola između pridjeva ili zamjenice i pripadajuće im imenice, člana i imenice, imenice i posvojnog, objektnog ili partitivnog genitiva itd.

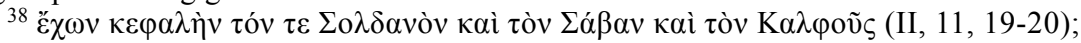

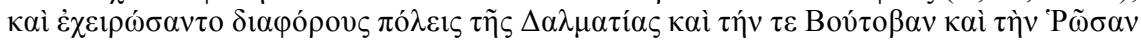

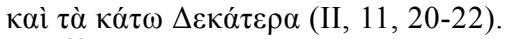

${ }^{39} \beta \alpha \sigma \imath \lambda$ cías B $\alpha \sigma \imath \lambda$ cíov $(29,88-89)$.

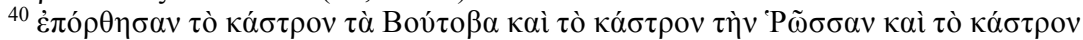

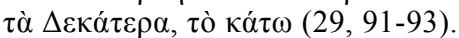

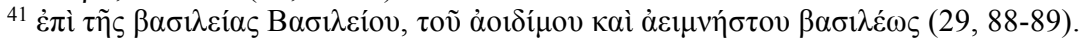


S druge strane, u Vita Bas. isti je zapis, osim što je prikazan opširnije, i stilski bogatiji:

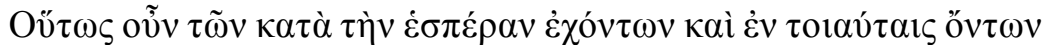

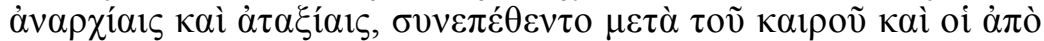

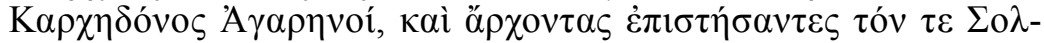

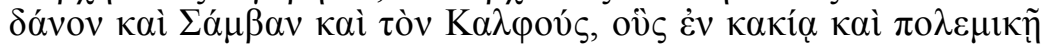

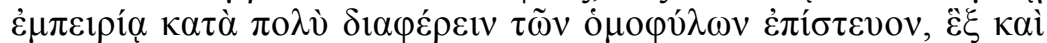

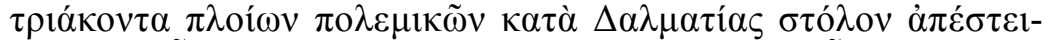

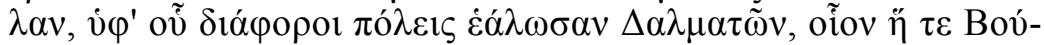

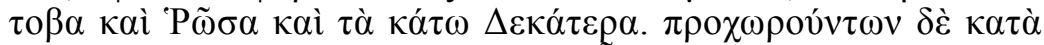

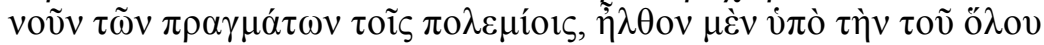

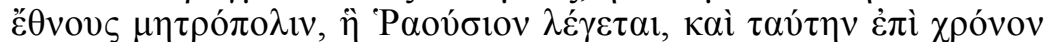

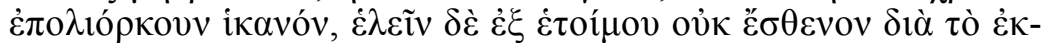

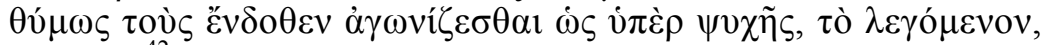
$\theta \dot{\varepsilon} \mathrm{ov \tau \alpha \varsigma} .{ }^{42}$

„Budući da je na zapadu vladalo takvo stanje, takva anarhija i nered, iskoriste priliku za napad Agareni iz Karhedona, i postavivši za zapovjednike Soldana, Sambu i Kalfusa, za koje su vjerovali da se među svojim drugovima ističu u pokvarenosti i ratnom iskustvu, pošalju na Dalmatiju brodovlje od trideset i šest lađa, koje osvoji različite dalmatinske gradove, kao što su Butova, Rosa i donja Dekatera. Kako je neprijateljima sve polazilo za rukom, dođu i do glavnoga grada čitavog naroda, koji se zove Rausij, i držahu ga pod opsadom dugo vremena. No nisu ga mogli smjesta osvojiti jer su se njegovi stanovnici hrabro borili, kao u trci za spas žive glave, kako kaže poslovica."

Osim većeg broja figura iskaza (tri homeoteleuta, ${ }^{43}$ tri hiperbata, ${ }^{44}$ jedna sinonimija ${ }^{45}$ i jedna zeugma $\left.{ }^{46}\right)$, autor Vita Bas. upotrijebio je i dvije figure mišljenja - gnomu ${ }^{47}$ i poredbu. ${ }^{48}$ Ovdje je zanimljivo promotriti na koji su način ova stilska sredstva uklopljena u tekst. Za razliku od De them. i De adm. imp. gdje se navodi u vrijeme čije je vladavine doplovilo arapsko brodovlje (De them. kaže „u vrijeme vladavine Mihaela, Teofilova sina”, a De adm. imp. „za vladavine Bazilija”), pisac Vita Bas. pripovijedanje započinje samo konstatacijom o neredu na zapadu, aludirajući pritom na Mihaelovu odgovornost za tako teško stanje; težina situacije i Mihaelov nemar u obavljanju carskih dužnosti

${ }^{42}$ Vita Bas., 53, 1-13.

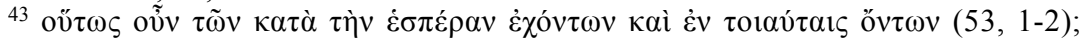

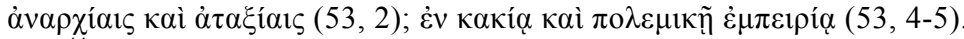

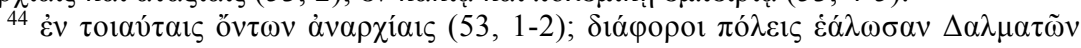

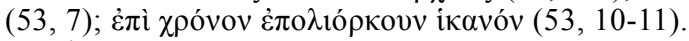

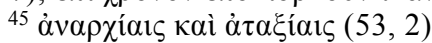

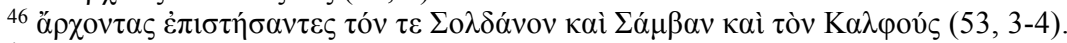

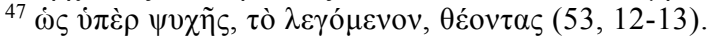

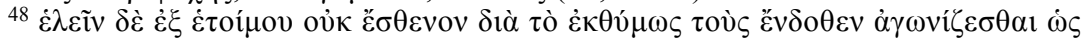

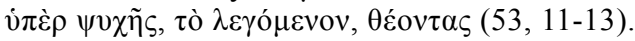




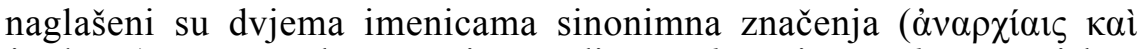

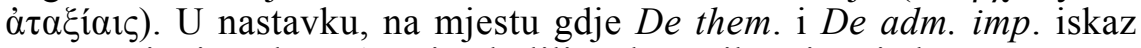
završavaju time da su Arapi opkolili Dubrovnik, pripovjedač u Vita Bas. koristi priliku da bi proširio svoju priču komentarom u nastavku kako neprijatelji ipak nisu smjesta uspjeli osvojiti spomenuti grad, jer su se „njegovi stanovnici hrabro borili, kao u trci za spas žive glave, kako kaže poslovica", gdje je upotrijebljena poredba u koju je uklopljen poslovični izraz. Od stilskih sličnosti među tim trima spisima koje smo uočili u tom dijelu teksta, istaknut ćemo da De them. i De adm. imp.. na istom mjestu koriste zeugmu, ${ }^{49} \mathrm{kad}$ se nabrajaju gradovi koje su Saraceni osvojili, a De them. i Vita Bas. zeugmu ${ }^{50}$ kad se spominju imena arapskih zapovjednika te hiperbat ${ }^{51} \mathrm{kad}$ se govori o vremenskom trajanju opsade Dubrovnika.

Molba dubrovačkog poslanstva. U nastavku priče čitamo kako su stanovnici Raguze, iscrpljeni dugotrajnom opsadom i bivajući u nevolji, zatražili od bizantskog cara da im pritekne u pomoć. Upravo u to vrijeme preminuo je car Mihael III., a vlast preuzeo njegov nasljednik na prijestolju Bazilije I., koji je uslišavši njihove molbe poslao brodovlje od sto lađa pod zapovjedništvom sposobnog Nikete Oorife. De them. i De adm. imp. ovdje su također koncizni, donoseći nam samo podatak o tome kako su stanovnici Raguze od bizantskog cara zatražili pomoć te kako im je Bazilije poslao bizantsku mornaricu.

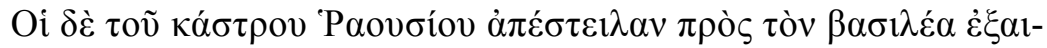

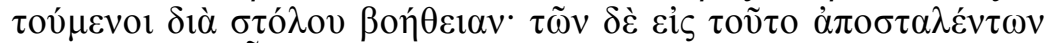

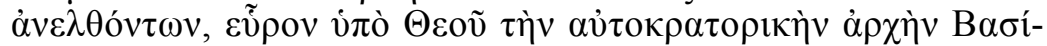

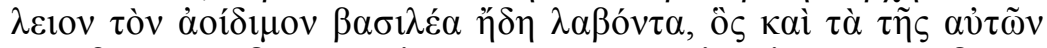

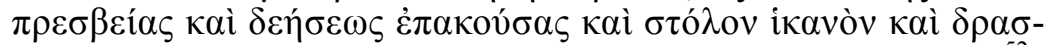

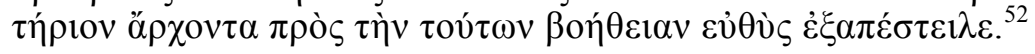

„Stanovnici kastruma Rausija pošalju caru poslanike tražeći pomoć u brodovlju; kad su poslanici došli, zateknu slavnog cara Bazilija gdje je već od Boga preuzeo samodržačku vlast. Poslušavši molbu njihovih poslanika, car im smjesta pošalje i dostatno brodovlje i poduzetnog zapovjednika u pomoć."

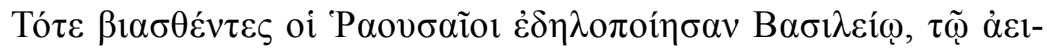

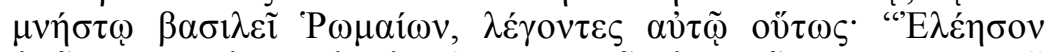

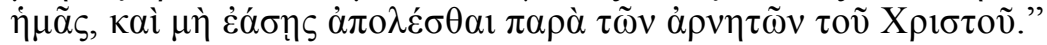

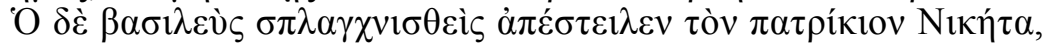

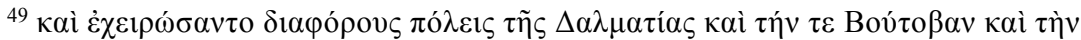

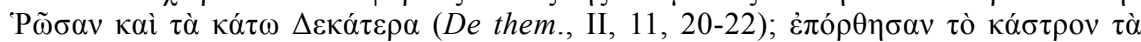

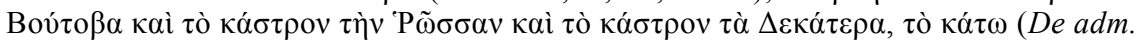
imp., 29, 91-93).

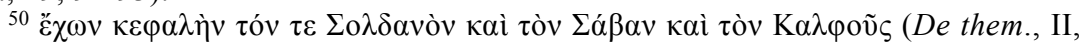

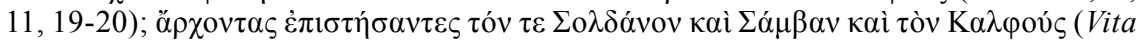
Bas., 53, 3-4).

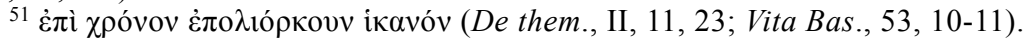

${ }^{52}$ De them., II, 11, 23-28. 


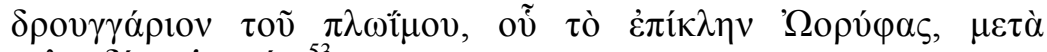
$\chi \varepsilon \lambda \alpha v \delta i ́ \omega v \dot{\varepsilon} \kappa \alpha \tau o ́ v .{ }^{53}$

„Pritiješnjeni nevoljom Rauseji se tad obrate Baziliju, rimskom caru vječne slave, govoreći mu ovako: „Smiluj nam se, i nemoj dopustiti da nas unište poricatelji Krista.” A car se smiluje i pošalje im patricija Niketu, drungarija mornarice, kojemu nadimak bijaše Oorifa, sa sto helandija."

Od upotrijebljenih stilskih figura, u De them. uočavamo isključivo figure iskaza - dva homeoteleuta, ${ }^{54}$ jednu etimološku figuru ${ }^{55} \mathrm{i}$ jednu zeugmu. ${ }^{56} \mathrm{U}$ De adm. imp. pisac je, nazvavši Arape ,poricateljima Krista", upotrijebio trostruki trop - isti bi izraz istovremeno bio antonomazija, metonimija i perifraza ${ }^{57}$ od ostalih je stilskih figura uklopio još samo etimološku figuru, ${ }^{58}$ no podigao je razinu stilskog izričaja ubacivanjem upravnog govora, što svakako unosi određenu dinamiku i živopisnost $\mathrm{u}$ iskaz.

U Vita Bas. taj je dio priče opet najduži i stilski najdorađeniji, jer su upotrijebljene i figure iskaza, i figure mišljenja, i tropi:

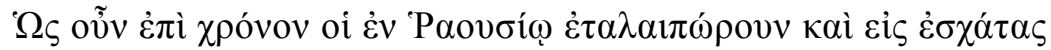

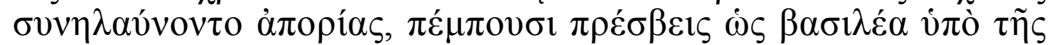

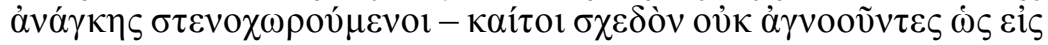
$\ddot{\alpha} \lambda \lambda \alpha \mu \alpha \tilde{\alpha} \lambda \lambda \sigma \nu$ ó $\kappa \rho \alpha \tau \tilde{\omega} v \dot{\alpha} \pi \eta \sigma \chi \delta ́ \lambda \eta \tau \alpha l-\dot{\varepsilon} \lambda \varepsilon \tilde{\eta} \sigma \alpha l \pi \alpha \rho \alpha \kappa \alpha \lambda \circ \tilde{v} v \tau \varepsilon \varsigma$

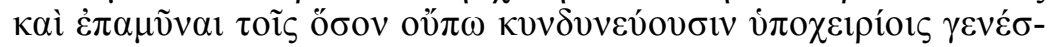

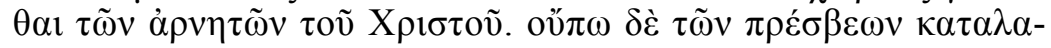

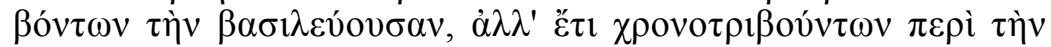

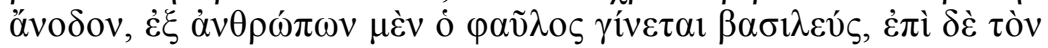

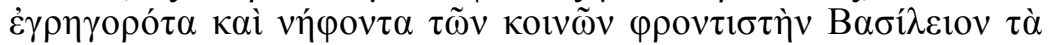

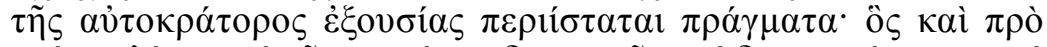

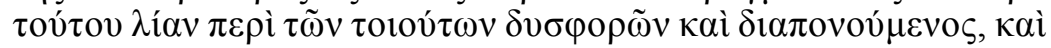

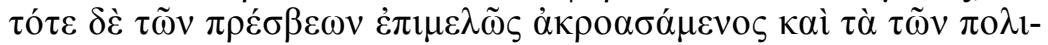

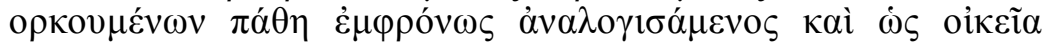

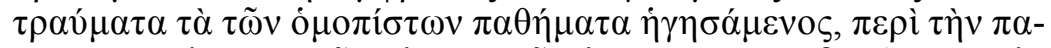

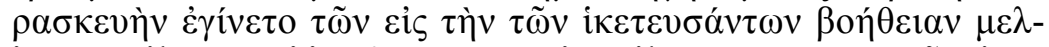

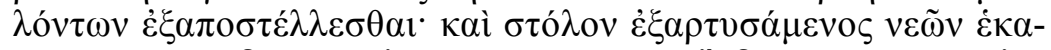

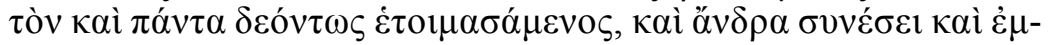

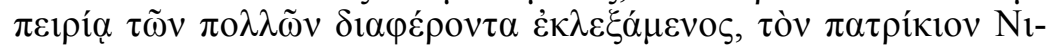

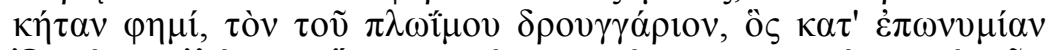
' $\pi \mathrm{o} \lambda \varepsilon \mu \mathfrak{i}^{\prime} \omega \mathrm{v} \dot{\varepsilon} \kappa \pi \varepsilon \dot{\varepsilon} \mu \pi \varepsilon{ }^{59}$

${ }^{53}$ De adm. imp., 29, 94-98.

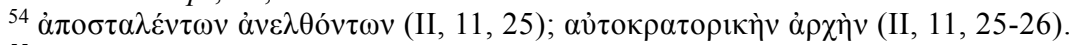

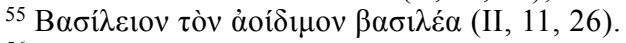

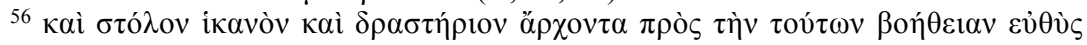
$\grave{\varepsilon} \xi \alpha \pi \varepsilon \dot{\varepsilon} \sigma \varepsilon 1 \lambda \varepsilon$ (II, 11, 27-28)

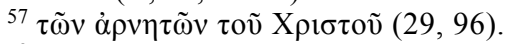

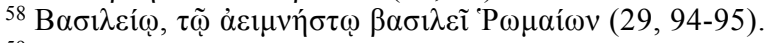

${ }^{59}$ Vita Bas., 53, 13-33. 
„Kako su oni u Rausiju dugo vremena podnosili breme i bili dovedeni do krajnje nevolje, pritiješnjeni nuždom pošalju caru poslanike - iako su dobro znali da je vladar zaokupljen drugim stvarima - moleći ga da se smiluje i pomogne onima koji su kao nikad prije u opasnosti da padnu u ruke poricatelja Krista. Dok još poslanici nisu stigli u carujući grad nego su bili na putu, napusti ovaj svijet nevaljali car, a samodržačka vlast prijeđe na Bazilija, budnoga i trijeznoga skrbnika za zajedničko dobro. On se i prije toga silno žalostio i ljutio zbog ovakvih stvari; saslušavši tad brižno poslanike, razumno procijenivši težak položaj opkoljenih i shvativši patnje istovjernika kao vlastite rane, dao se u pripremu onoga što je trebalo poslati u pomoć onima koji su mu se utekli. Opremivši brodovlje od sto lađa, pripremivši sve kako dolikuje i izabravši čovjeka koji se nad mnogima isticao mudrošću i iskustvom - mislim na patricija Niketu, drungarija mornarice, kojemu nadimak bijaše Oorifa - pošalje ga kao neki vatreni grom na neprijatelje."

Od figura iskaza uočljiva su tri homeoteleuta, ${ }^{60}$ pet hiperbata, ${ }^{61}$ dva izokolona, ${ }^{62}$ dva polisindetona ${ }^{63}$ i jedan asindeton, ${ }^{64}$ od figura mišljenja jedna antiteza, ${ }^{65}$ jedna gradacija ili klimaks ${ }^{66}$ jedna parente-

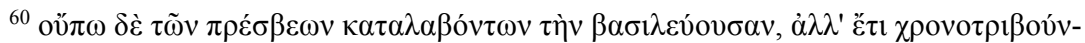

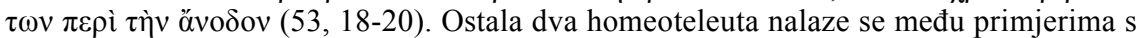
izokolonom.

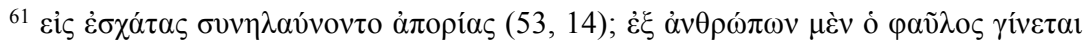

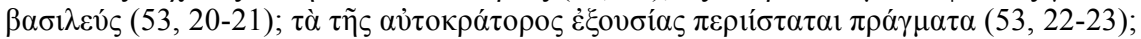

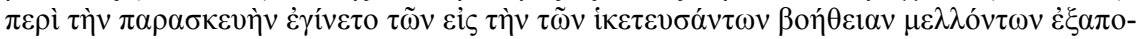

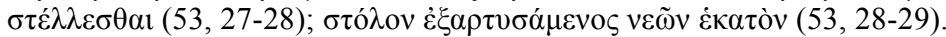

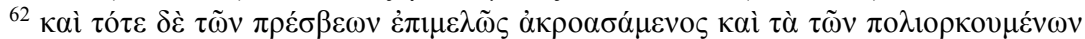

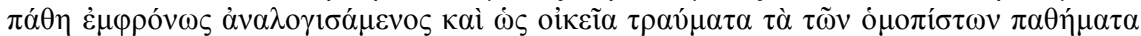

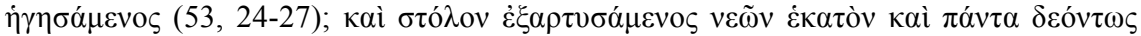

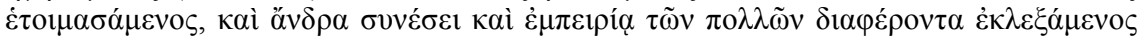
$(53,28-31)$.

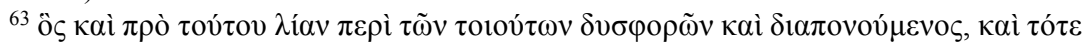

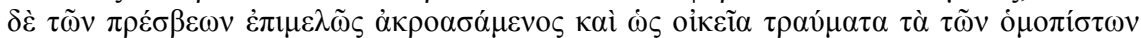

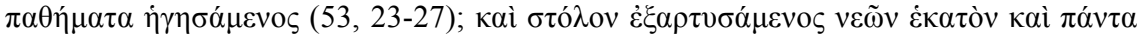

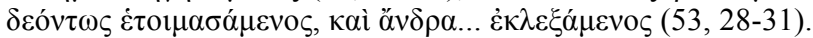

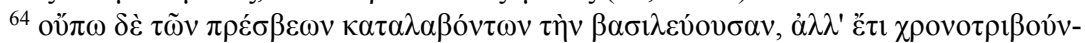

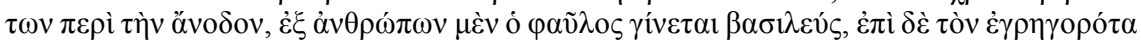

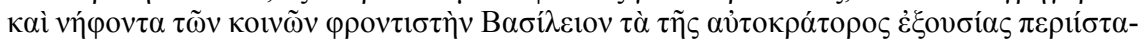
$\tau \alpha 1 \pi \rho \alpha ́ \gamma \mu \alpha \tau \alpha(53,18-23)$.

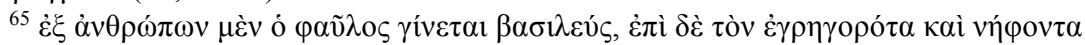

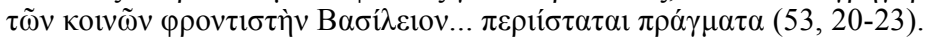

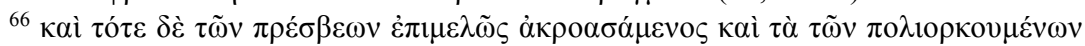

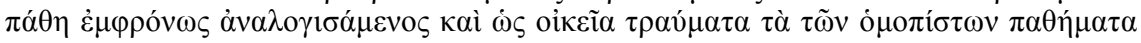
$\dot{\eta} \gamma \eta \sigma \alpha ́ \mu \varepsilon v o \varsigma(53,24-27)$. Iako antički retoričari gradaciju ili klimaks definiraju kao proširenu i uvišestručenu anadiplozu u kojoj se jedinice s krajeva dijelova iskaza ponavljaju na počecima sljedećih dijelova te je time ubrajaju u figure iskaza (Heinrich Lausberg, Handbook of Literary Rhetoric: A Foundation for Literary Study, ed. by David E. Orton and R. Dean Anderson (Leiden-Boston-Köln: Brill, 1998), 279-280), ovdje kao primjer 
$\mathrm{za}^{67}$ i dvije poredbe, ${ }^{68}$ a od tropa po jedna antonomazija, ${ }^{69}$ metonimija ${ }^{70}$ i litota ${ }^{71}$ te dvije perifraze. ${ }^{72}$

Taj će nam izdvojeni segment moći poslužiti kao dobar primjer da bismo predočili koliko je značajna razlika u stilskoj intervenciji u predložak među ovim trima Konstantinovim spisima. Na početku epizode, kad se govori da su Dubrovčani poslali caru poziv u pomoć, $D e$ them. ne navodi u koliko su teškom stanju oni bili, dok De adm. imp. samo kaže ,pritiješnjeni nevoljom Rauseji...”. S druge strane, u Vita Bas. u nekoliko se navrata naglašava težina opsade stanovnika dotičnoga grada; oni su „,dugo vremena podnosili breme”, ,dovedeni do krajnje nevolje” šalju caru poslanike ,pritiješnjeni nuždom”, nakon čega upotrebom figure misli parenteze pisac umeće misao kako su istovremeno „dobro znali da je vladar zaokupljen drugim stvarima”, gdje nalazimo i

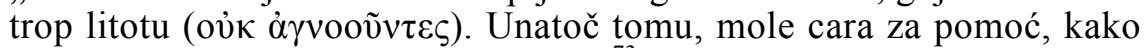
ne bi pali u ruke ,poricatelja Krista". ${ }^{73}$ Pripovjedač je ovdje iskoristio prigodu da se caru Mihaelu naruga riječima kako se bavio drugim stvarima umjesto da brani državu; ${ }^{74}$ teško možemo vjerovati da su to kazali dubrovački poslanici, odnosno da to nije osobni Konstantinov dodatak. Nadalje, ne možemo se oteti dojmu kako se namjerno i konstantno ističe težina situacije u kojoj se nalaze stanovnici Raguze, kako bi se time istaknula Bazilijeva značajna uloga u tom događaju - Ragužani su u izuzetno teškoj poziciji, Mihael je u tim trenucima zauzet drugim poslovima, a Bazilije im spremno šalje pomoć. Potom nam Vita Bas. donosi

te stilske figure navodimo i mjesta bez anadiploze, gdje se izborom riječi odnosno misli uočava stupnjevanje od niže ka višoj točki; iz tog smo razloga ovdje gradaciju svrstali u figure misli (usp. Krešimir Bagić, Rječnik stilskih figura (Zagreb: Školska knjga, 2012), 126-129).

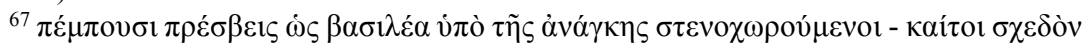

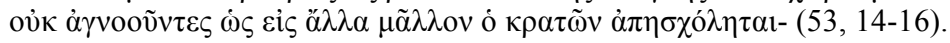

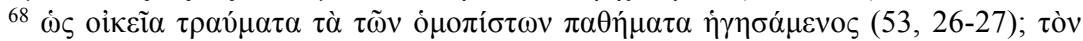

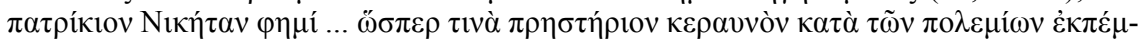
$\pi \varepsilon 1(53,31-33)$.

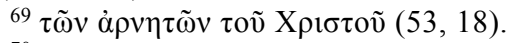

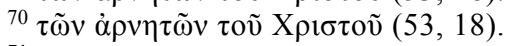

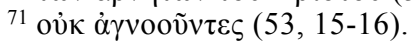

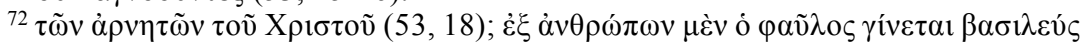
(53, 20-21).

${ }^{73}$ Isti je izraz upotrijebljen i u De adm. imp., 29, 96.

${ }^{74}$ Opis Mihaelove vladavine i njegova raskalašenog načina života, od strasti za konjima, pijankama i gozbama, rasipanja državnog novca, sve do povrede svetih crkvenih obreda, donosi ekskurs o Mihaelovu životu u Vita Bas., 20-27. No, čini se da Porfirogenet u tom opisu nije bio u potpunosti objektivan, nastojeći što više ocrniti Bazilijeva prethodnika na prijestolju; svrha bi Mihaelova psogosa pritom bila stvoriti kontrast u odnosu na vrline koje Bazilijeve posjeduje u izobilju i koje ga čine dobrim kršćanskim carem. O Konstantinovu prikazu Mihaela vidi Romilly J. H. Jenkins, "Constantine VII's Portrait of Michael III", Bulletin de la Classe des lettres et des sciences morales et politiques, Académie Royale de Belgique (5e Série) 34 (1948), 71-77 (pretisak u Romilly J. H. Jenkins, Studies on Byzantine History of the Ninth and Tenth Centuries, no. 1 (London: Variorum, 1970)). Usp. i Bury, History, 162-164. 
podatak kako je, dok su poslanici još uvijek bili na putu, preminuo „nevaljali car”, a vlast prešla na Bazilija, „budnoga i trijeznoga skrbnika za zajedničko dobro". Dok u De them. i De adm. imp. zatječemo samo Bazilijevo ime, upotrebom perifraze „nevaljali car” pisac Vita Bas. vješto izbjegava spominjanje imena cara Mihaela III., aludirajući time na to kako je on bio tako loš vladar, da mu ni ime nije vrijedno spomena. Upotrebom epiteta "nevaljali”, stvara se kontrast u odnosu na epitete „budan” i „trijezan” koji su pridjenuti Baziliju, a čitava je ta misao zaokružena antitezom kojom se naglašavaju Bazilijeve pozitivne osobine $u$ odnosu na Mihaelove negativne crte.

Bazilijeva je reakcija na molbu dubrovačkih poslanika u svim trima spisima jednako opisana u stvarnim elementima, samo što je Vita Bas., kao i obično, izdašnija u stilu i u lako domislivim detaljima. Ondje stoji kako se Bazilije i prije toga žalostio zbog takvih događaja te kako se, brižljivo poslušavši poslanike i sagledavši njihove patnje kao vlastite, dao u pripremu pomoći; pisac je ovdje upotrijebio izokolon, u kojem se značajan zvučni efekt postiže homeoteleutom tj. nizanjem parti-

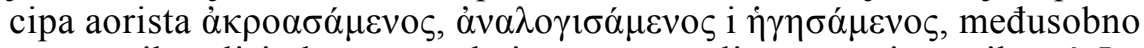

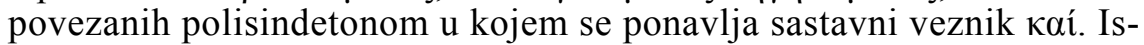
tim tim participima postignut je i klimaks, gdje je stupnjevanje dočarano time što je Bazilije najprije „poslušao” poslanike, zatim ,procijenio” njihov težak položaj, da bi na kraju njihove patnje „shvatio" kao vlastite, gdje je upotrijebljena i poredba. Izokolon nalazimo i u sljedećim retcima, u sklopu kojega uočavamo homeoteleut $\dot{\varepsilon} \xi \alpha \rho \tau v \sigma o ́ \mu \varepsilon v o \varsigma, ~ \dot{\varepsilon} \tau o \iota \mu \alpha-$ $\sigma \alpha ́ \mu \varepsilon v o \varsigma$ i $\dot{\varepsilon} \kappa \lambda \varepsilon \xi \alpha \dot{\alpha} \mu \varepsilon v o \varsigma$, također izražen upotrebom participa aorista povezanih veznikom кaí (polisindeton). Koliko je poznato, Bazilije nije osobno sudjelovao u toj vojnoj intervenciji, i čini nam se kako pripovjedač izborom ovih riječi upravo želi objasniti carevu ključnu ulogu koja se sastojala u tome da je opremio brodovlje, uredio sve kako priliči i izabrao najboljeg zapovjednika kojeg će poslati. Ova cjelina završava imenom Nikete Oorife, zapovjednika bizantske mornarice, za kojeg autor upotrebom poredbe kaže da ga je car poslao „kao vatreni grom” na neprijatelje; s druge strane, u De adm. imp. navodi se samo ime zapovjednika ali bez metaforičkih poredbi, dok je u De them. ime izostavljeno, umjesto čega stoji samo ,poduzetni zapovjednik”.

Prekid opsade Dubrovnika i napad na Bari. Nakon što je Bazilije dalmatinskim plemenima poslao pomoć, Saraceni prelaze na Apeninski poluotok, osvajaju Bari te ostale gradove na jugu Italije sve do Rima. Umjesto nejasnog podatka o četrdeset godina vladavine Saracena na jugu Italije u De adm. imp., De them. i Vita Bas. govore o stotinu i pedeset opustošenih gradova. Sutnja o pretjeranom trajanju okupacije ovdje se nameće kao ispravak očite netočnosti, no i dalje ostaje teško razumljivim odakle podatak o broju gradova i zašto ga u De adm. imp. nema.

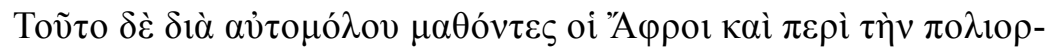

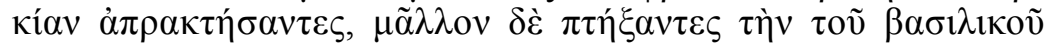

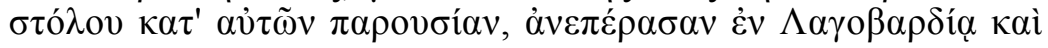




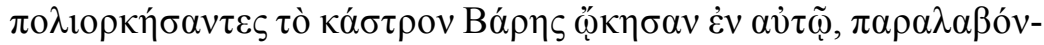

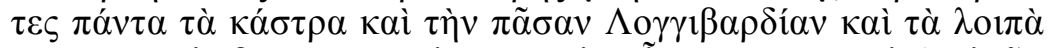

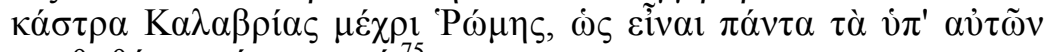

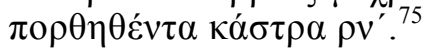

\begin{abstract}
„Afri doznaše to preko prebjega i ne uspjevši u opsadi, a još više prestrašivši se dolaska careve mornarice, prijeđu u Lagobardiju i opkolivši kastrum Bari nastane se u njemu. Osvojili su sve kastrume i čitavu Longibardiju te ostale kastrume u Kalabriji sve do Rima, tako da je od njih bilo razoreno sveukupno stotinu i pedeset kastruma."

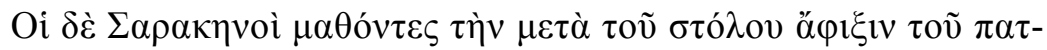

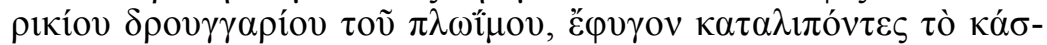

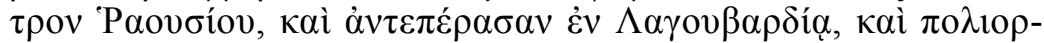

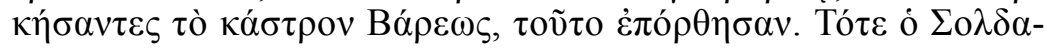

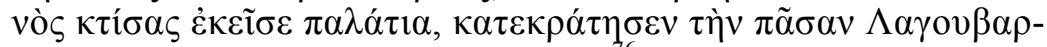

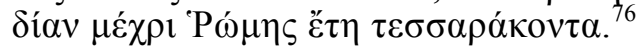

„Saznavši da patricij, drungarij mornarice, dolazi s lađama, Sarakeni pobjegnu ostavivši kastrum Rausij i prijeđu u Lagubardiju, opkole kastrum Bari i razore ga. Sazdavši ondje palaču Soldan tada zavlada čitavom Lagubardijom sve do Rima četrdeset godina."

Taj je dio priče u De them. i De adm. imp. također minimalno stiliziran, gdje uočavamo samo nekoliko figura iskaza te dvije mišljenja. U De them. od figura iskaza prisutni su jedan homeoteleut ${ }^{77} \mathrm{i}$ jedna zeugma $^{78}$ te od figura mišljenja jedan hijazam, ${ }^{79}$ a u De adm. imp. jedan izokolon s homeoteleutom ${ }^{80}$ kao figura iskaza te jedan hijazam ${ }^{81}$ kao figura mišljenja.

Vita Bas. i u ovom dijelu priče donosi opširnije izvješće. Prekid opsade Dubrovnika te prelazak Saracena u Italiju, gdje su osvojili Bari i ostale gradove sve do Rima, opisan je na kraju 53. poglavlja. Tu nalazimo od figura iskaza jedan asindeton ${ }^{82} \mathrm{i}$ jedan polisindeton, ${ }^{83} \mathrm{dva}$

${ }^{75}$ De them., II, 11, 28-34.

${ }^{76}$ De adm. imp., 29, 98-103.

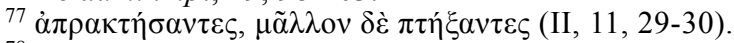

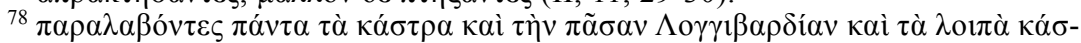

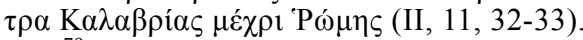

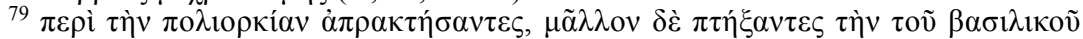

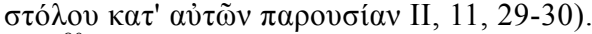

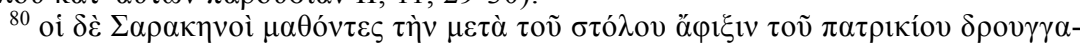

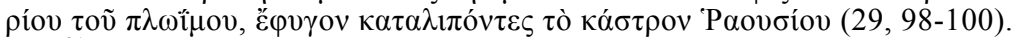

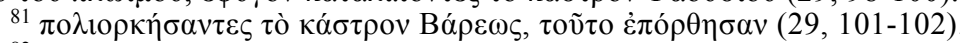

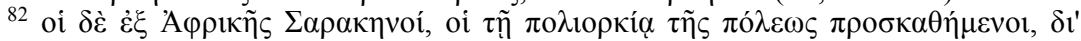

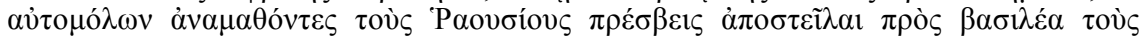

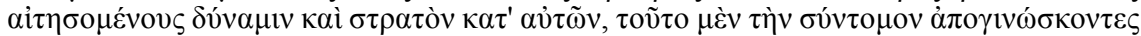

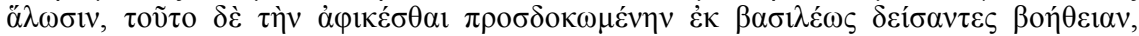

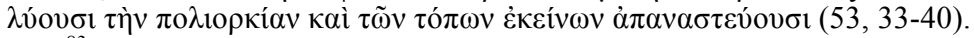

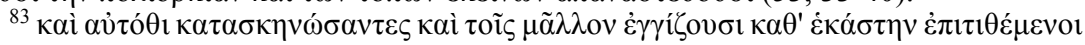

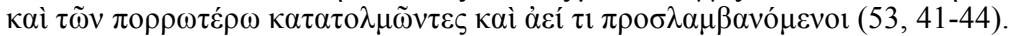


homeoteleuta, ${ }^{84}$ jedan hiperbat ${ }^{85}$ i jedan hendiadioin. ${ }^{86}$ Od figura mišljenja autor je upotrijebio dva hijazma, ${ }^{87}$ od kojih je prvi u kombinaciji s hiperbatom. ${ }^{88}$

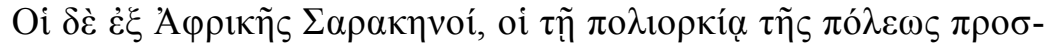

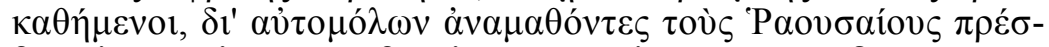

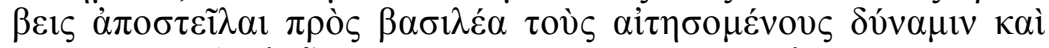

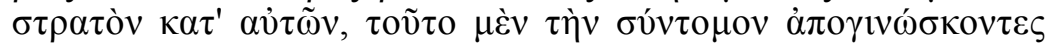

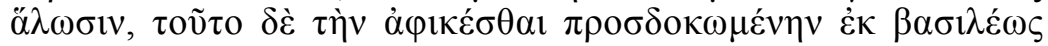

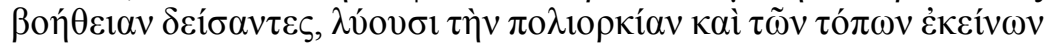

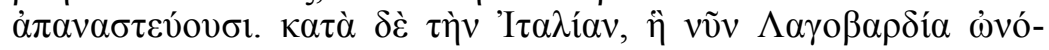

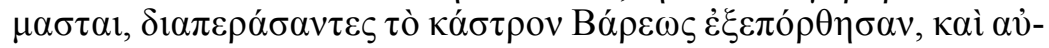

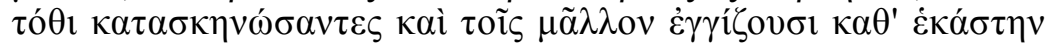

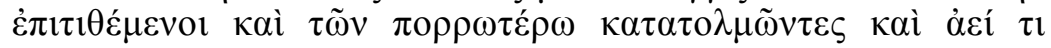

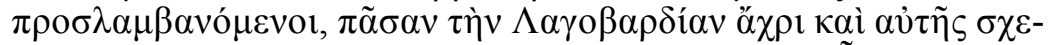

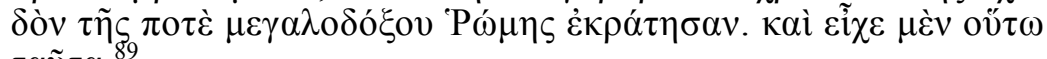
$\tau \alpha \tilde{v} \tau \alpha$.

„A Sarakeni iz Afrike koji su opsjedali grad, doznavši preko prebjega kako su Rauseji poslali caru poslanike da zatraže vojnu silu protiv njih, s jedne strane gubeći nadu u brzo osvajanje, a s druge uplašivši se pomoći koja je trebala pristići od cara, prekinu opsadu i povuku se iz tih krajeva. Prešavši u Italiju, koja se sad naziva Lagobardijom, razore kastrum Bari i nastane se ondje, te svakodnevno napadajući susjede i prijeteći onima koji su živjeli dalje, i stalno osvajajući nova područja, zavladaju čitavom Lagobardijom gotovo do samog nekoć vrlo slavnog Rima. I bijaše tomu tako."

Dok u tom dijelu iskaza De adm. imp. samo donosi podatak da su Saraceni, saznavši za dolazak bizantske mornarice s njihovim zapovjednikom, prekinuli opsadu Dubrovnika i pobjegli u Italiju, gdje je pisac upotrijebio izokolon s homeoteleutom, De them. i Vita Bas. podudarni su u tome da su Arapi od prebjega saznali da su Ragužani zatražili carevu pomoć te da su se preplašili dolaska bizantskih ratnih brodova, nakon čega su prekinuli opsadu. Važnost obavijesti o tome kako Arapima nije uspjela opsada i kako su se uplašili dolaska carevih lađa

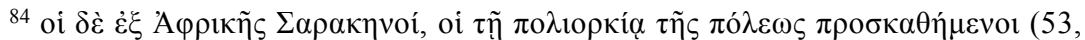

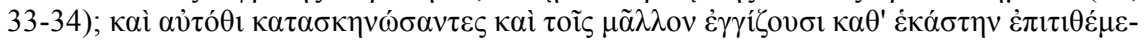

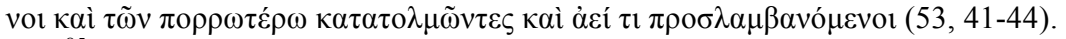

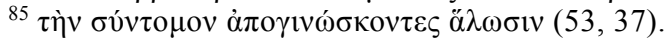

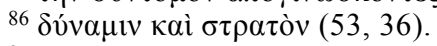

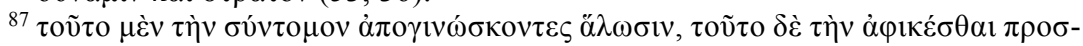

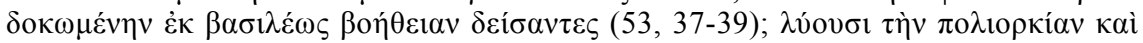
$\tau \tilde{\omega} \nu \tau$

${ }^{88}$ Monotoniju koja bi proizišla iz učestale upotrebe izokolona i hijazama pisac Vita Bas. izbjegava na taj način da često te dvije stilske figure kombinira s hiperbatom. Popis takvih primjera vidi u Serreqi Jurić, "Usporedba jezično-stilskih osobitosti”, 211-212, 216, 234, 237-238.

${ }^{89}$ Vita Bas., 53, 33-45. 
autor obaju spisa naglasio je upotrebom stilskih izražajnih sredstava u De them. unakrsno je poredao dva participa aorista i njihove objekte

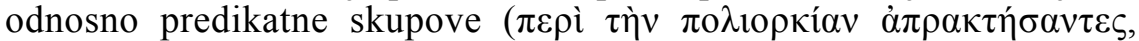

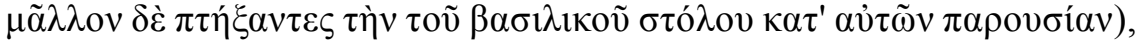
dok je u Vita Bas. na tom mjestu također uklopio hijazam, ali u kombi-

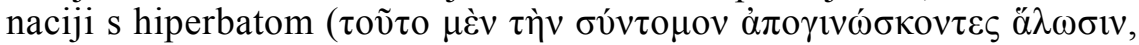

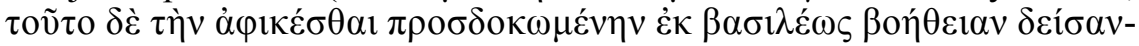
$\tau \varepsilon \varsigma)$, želeći naglasiti razloge zbog kojih su Arapi prekinuli opsadu - s jedne strane jer su izgubili nadu da će u kratko vrijeme osvojiti grad, a s druge jer su se uplašili dolaska careve pomoći, nakon čega nalazimo

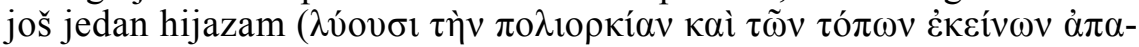

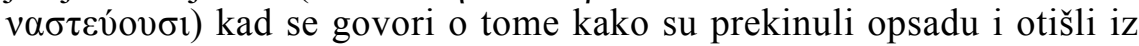
tih krajeva. Brzinu prekida opsade i hitri prelazak u Italiju pripovjedač je u Vita Bas. živopisno dočarao asindetonom odnosno nizanjem kratkih nezavisnih rečenica bez veznika, a u nastavku je, u namjeri da prikaže intenzitet arapskog pustošenja po italskom tlu, upotrijebio polisindeton

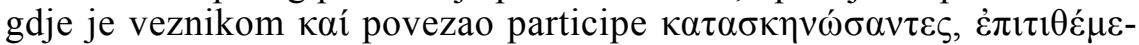
vol, $\kappa \alpha \tau \alpha \tau 0 \lambda \mu \tilde{\omega} v \tau \varepsilon \varsigma, \pi \rho \circ \sigma \lambda \alpha \mu \beta \alpha v o ́ \mu \varepsilon v o l$, poredavši ih na taj način da se homeoteleutom postiže uočljiv zvučni učinak.

Priča se u Vita Bas. zatim proteže na 55. poglavlje (54. se poglavlje bavi pokrštenjem Slavena), donoseći vijest o tome kako su Saraceni pustošeći i pljačkajući osvojili stotinu i pedeset gradova u Italiji, gdje su od figura iskaza upotrijebljeni jedan izokolon ${ }^{90} \mathrm{i}$ jedna sinonimija, ${ }^{91}$ te od tropa jedna metonimija: ${ }^{92}$

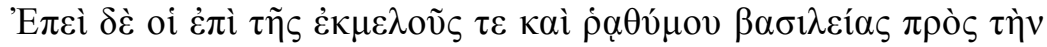

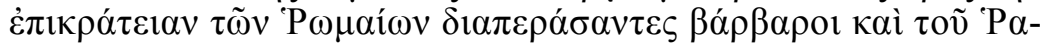

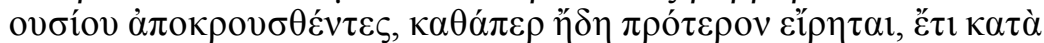

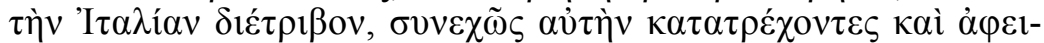

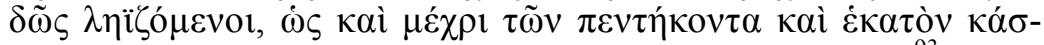

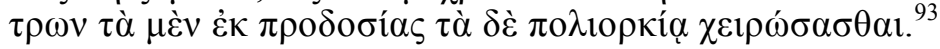

„Dok su barbari, koji su za vrijeme nemarne i lakomislene vladavine prodrli u rimska područja te bili odbijeni od Rausija, kao što je već prije bilo rečeno, još uvijek boravili u Italiji, neprestano je pustošeći i bezobzirno pljačkajući, tako da su pokorili stotinu i pedeset kastruma, što izdajom, što opsadom."

Pripovjedač iskaz započinje ponovnim iznošenjem optužbe protiv cara Mihaela (,za vrijeme nemarne i lakomislene vladavine”), gdje nalazimo metonimiju u kojoj je apstraktnom imenicom $\beta \alpha \sigma i \lambda \varepsilon i ́ \alpha$, vladavina" zamijenjena konkretna $\beta \alpha \sigma \lambda \lambda \varepsilon v ́ \varsigma$,,vladar", a kad uz nju domislimo epitete „nemaran” i „lakomislen”, prilično je jasno o kojem je caru riječ; znakovito je da je i ovdje izostavljeno Mihaelovo ime, kao što je to bio slučaj i u 53. poglavlju. Okrutnost arapskog divljanja po Italiji naglašena

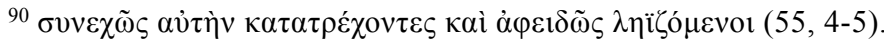

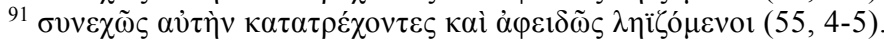

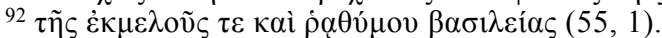

${ }^{93}$ Vita Bas., 55, 1-6.
} 


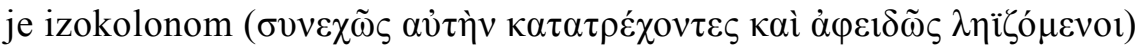

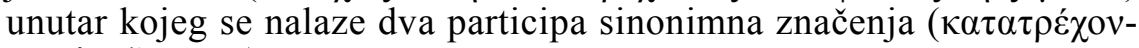
$\tau \varepsilon \varsigma, \lambda \eta і \zeta o ́ \mu \varepsilon v o 1)$.

Protunapad trojnog saveza i podjela ratnog plijena. Pogledajmo na kraju kako car-pisac završava priču o ovom važnom događaju iz povijesti Bizantskog carstva. Kad je Bazilije dobio vijest o tome da su Saraceni pokorili južnu Italiju, poslao je u pomoć sto ratnih brodova, ali je u isto vrijeme zamolio franačkog kralja Ludovika II. i papu da mu pomognu, čemu su se oni i odazvali te zajedničkim snagama uspjeli osvojiti Bari i zarobiti Soldana, nakon čega je Bizant ponovno zavladao tim područjem. ${ }^{94}$ Oslobođenje je Barija u svim trima spisima opisano iz bizantske perspektive - precizna vijest o tome da ga je ponovo osvojio Ludovik II. zamagljena je iskazom kako se trojni savez ujedinio i zajedničkim snagama porazio Saracene. Izvještaj u De them. i De adm. imp. i u tom dijelu priče pokazuje jednostavnije stilske osobitosti:

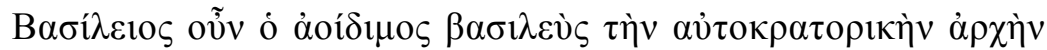

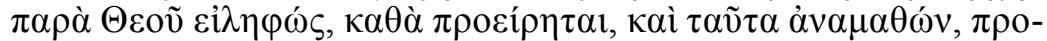

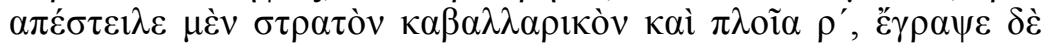

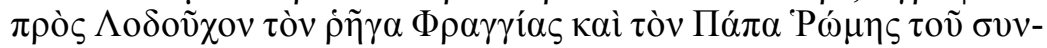

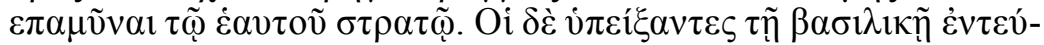

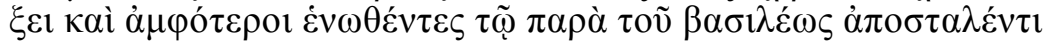

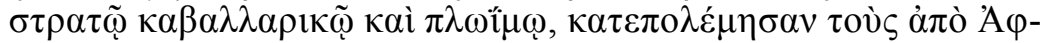

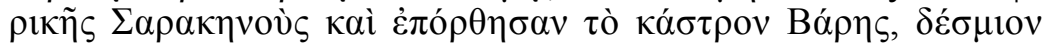

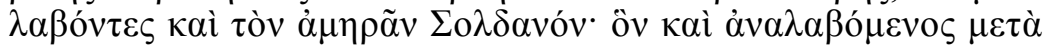

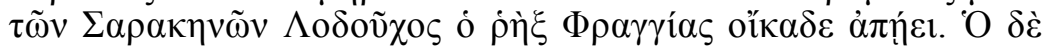

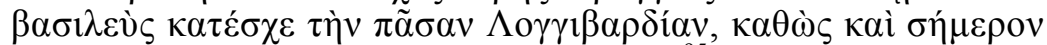

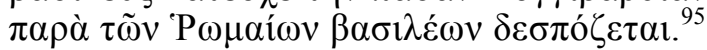

„Slavni car Bazilije, preuzevši od Boga samodržačku vlast, kao što je prije rečeno, i doznavši to, pošalje prije konjaničku vojsku i sto lađa te poruči pismenim putem frangijskom kralju Loduhu i rimskom papi da priteknu u pomoć njegovoj vojsci. Poslušavši carevu molbu, obojica se ujedine s konjaničkom i mornaričkom vojskom poslanom od cara, zarate na Sarakene iz Afrike i razore kastrum Bari, zarobivši i emira Soldana. Njega zajedno sa Sarakenima uzme frangijski kralj Loduh i ode kući. A car zadobije pod svoju vlast čitavu Longibardiju, kao što i dan danas njome vladaju rimski carevi."

94 Većina komentatora (Hirsch, Byzantinische Studien, 254, 258; Bury, "Rasprava", 118; Šišić, Povijest Hrvata, 350; Ferjančić, Vizantiski izvori, 17, bilj. 29; Georgije Ostrogorski, Povijest Bizanta 324.-1453., prev. Marina Miladinov i Kiril Miladinov (Zagreb: Golden marketing, 2002, 123) ističe kako je Bari zauzeo Ludovik, osim Jenkinsa koji u Commentary, 104-105, spominje mogućnost da je i bizantska vojska sudjelovala u tome. Bari je Bizantu pripao tek 875., poslije Ludovikove smrti, prema Ferjančić, Vizantiski izvori, 19, bilj. 32, ili krajem 876., prema Hirsch, Byzantinische Studien, 258.

${ }^{95}$ De them., II, 11, 34-44. 


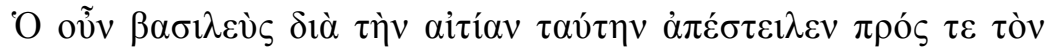

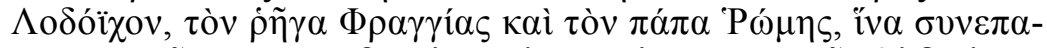

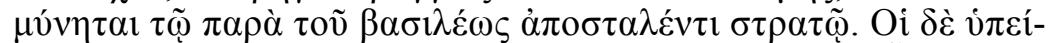

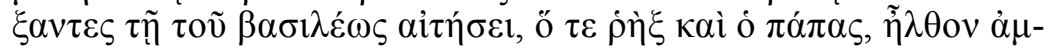

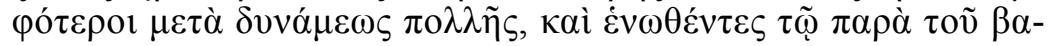

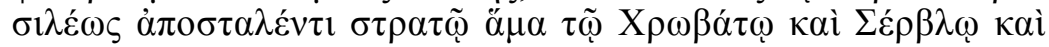

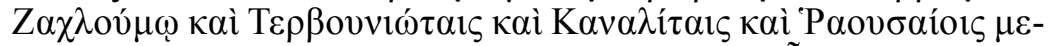

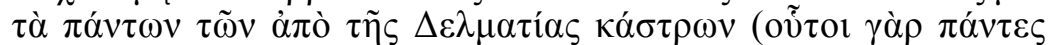

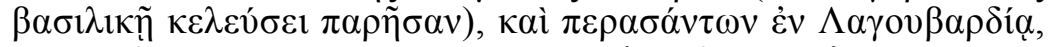

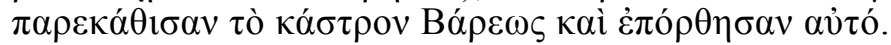

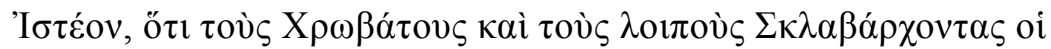

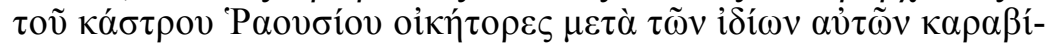

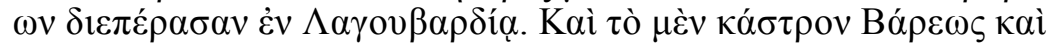

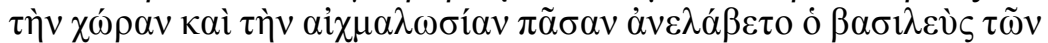

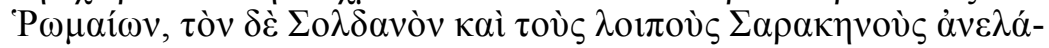

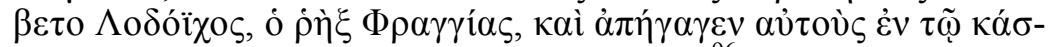

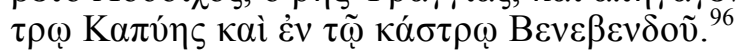

„Iz tog dakle razloga car pošalje molbu frangijskom kralju Lodoihu i rimskom papi da pomognu vojsci poslanoj od cara. Kralj i papa poslušaju carevo traženje te oba dođu s velikom vojskom, i ujedinivši se s vojskom poslanom od cara zajedno s Hrovatom, Serblom, Zahlumom, Terbuniotima, Kanalitima i Rausejima sa svim stanovnicima dalmatinskih kastruma (svi ovi bijahu nazočni po carevoj zapovijedi), prijeđu u Lagubardiju, opkole kastrum Bari i razore ga. Treba znati, da su Hrovate i ostale Sklavarhonte stanovnici kastruma Rausija svojim vlastitim korabljama prevezli u Lagubardiju. Kastrum Bari, zemlju i sve zaplijenjeno uzme rimski car, a Soldana i ostale Sarakene uzme frangijski kralj Lodoih te ih odvede u kastrum Kapiju i u kastrum Benevend."

Autor obaju spisa upotrijebio je samo figure iskaza: u De them. tri izokolona, ${ }^{97}$ od kojih je jedan s homeoteleutom, ${ }^{98}$ dvije zeugme ${ }^{99} \mathrm{i}$ jednu

${ }^{96}$ De adm. imp., 29, 103-119.

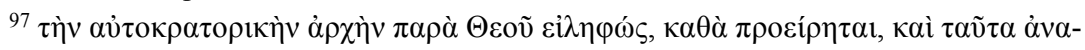

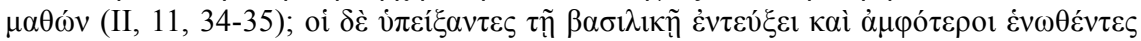

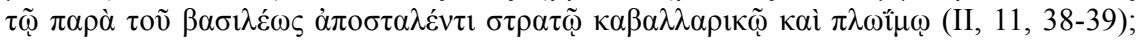

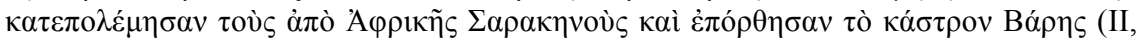
11, 39-40). Osim mjesta gdje je paralelizam prisutan u uzastopnim kolonima, kao izokolone smo tretirali i primjere gdje su koloni razdvojeni umetanjem većeg ili manjeg broja riječi, ali je ipak vidljivo da pisac ciljano poštuje jednaki slijed rečeničnih elemenata. Takav je primjer iz De them., II, 11, 34-35, naveden u ovoj bilješci, te primjer iz De adm. imp., 29, 106-108, naveden niže u bilješci 103.

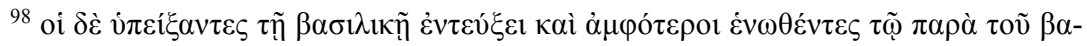

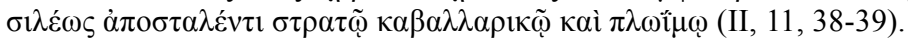

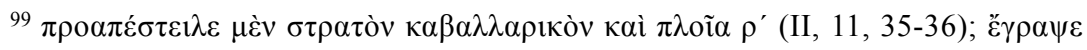

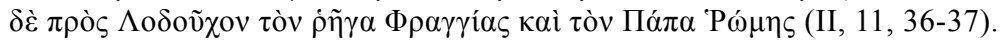


etimološku figuru, ${ }^{100}$ a u De adm. imp. tri izokolona, ${ }^{101}$ dva homeoteleuta ${ }^{102}$ i četiri zeugme. ${ }^{103}$ Gledajući s pozicije iznesenih historiografskih podataka, izvještaj je u De adm. imp. detaljniji, jer donosi informaciju o tome koja su dalmatinska plemena zajedno s carevom vojskom sudjelovala u borbi protiv Saracena te kako su Hrvate i ostale slavenske poglavare svojim lađama u Italiju prevezli stanovnici Raguze, što se ne navodi u De them.

Pisac Vita Bas. i dalje je retorički opširan, ne kazujući pritom ništa novo u odnosu na preostala dva spisa, no unoseći detalje kojima uveličava Bazilijevu ulogu u tom povijesnom događaju:

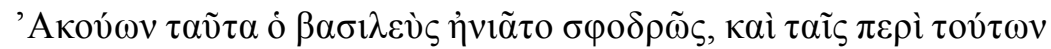

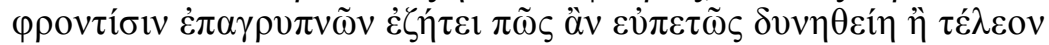

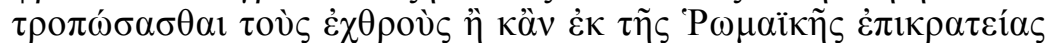

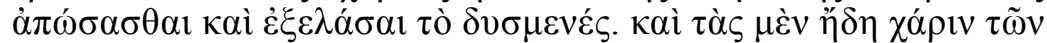

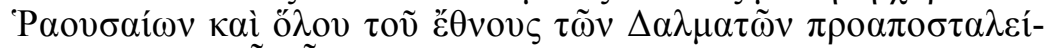

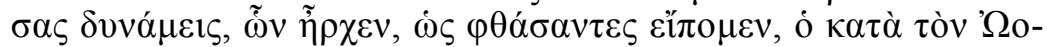

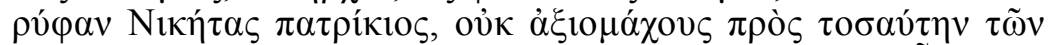

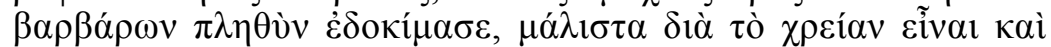

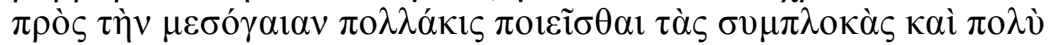

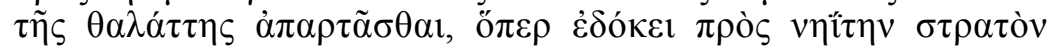

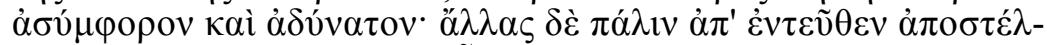

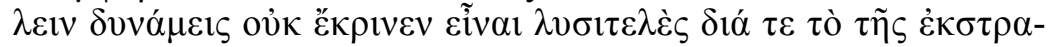

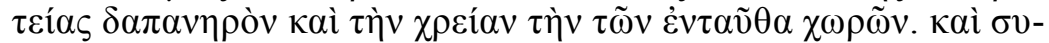

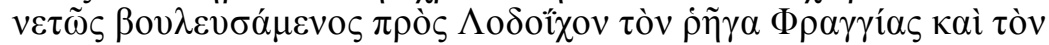

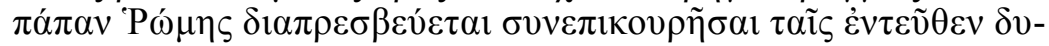

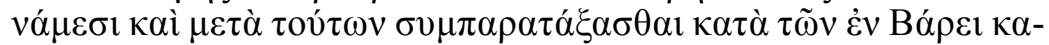

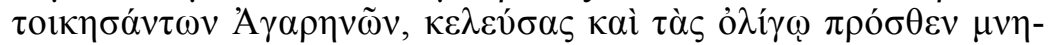

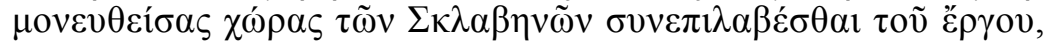

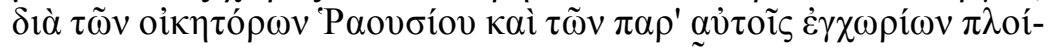

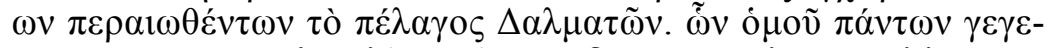

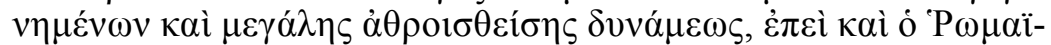

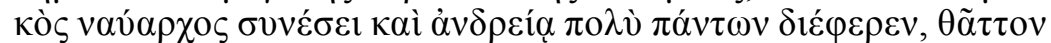

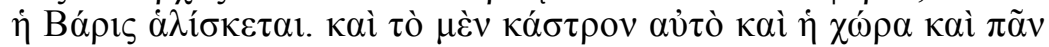

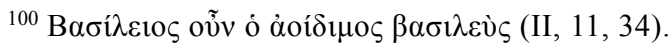

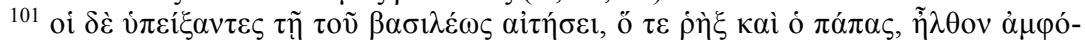

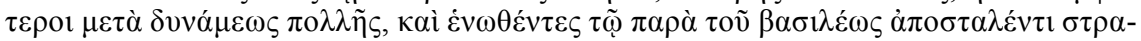

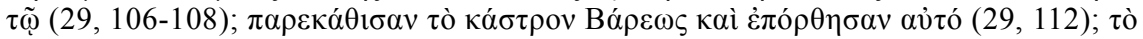

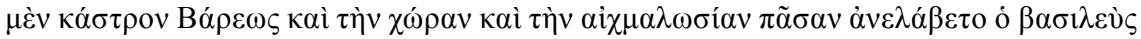

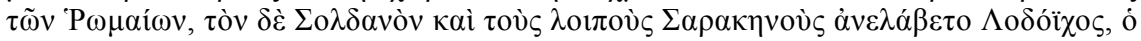

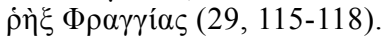

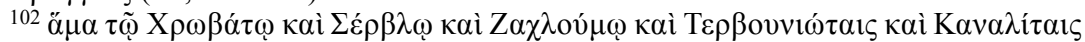

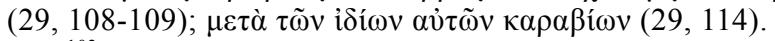

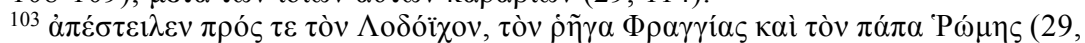

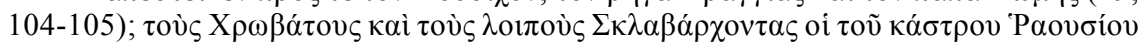

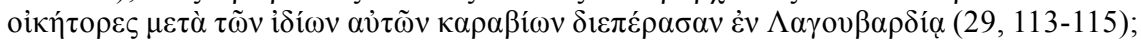
$\tau$

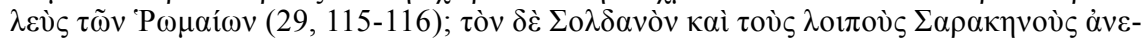

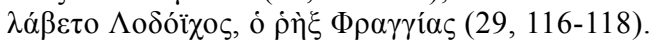




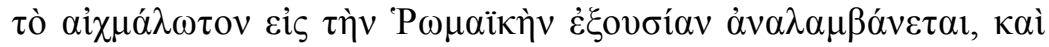

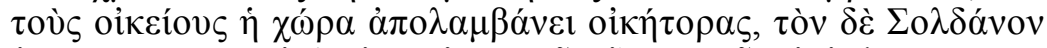

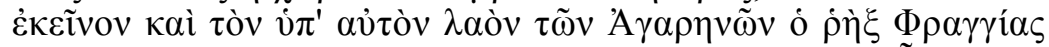

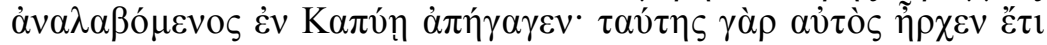

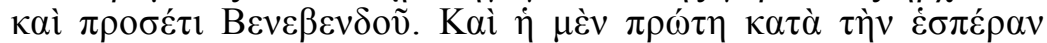

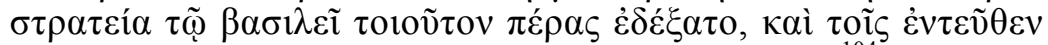

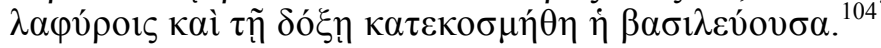

„Kad je car to čuo, bijaše silno žalostan, i bdijući od brige oko toga tražio je kako bi bez velikog napora mogao ili sasvim poraziti neprijatelja, ili potisnuti i istjerati zlo s rimskog područja. Shvatio je da vojna snaga koja je još ranije poslana radi Rauseja i cijelog dalmatinskog naroda, kojom je zapovijedao, kako smo prije rekli, patricij Niketa zvani Oorifa, nije dorasla tolikom mnoštvu barbara, najviše zbog toga što je bilo potrebno često voditi borbe u unutrašnjosti i dosta se udaljavati od mora, što se za pomorsku vojsku činilo nesvrsishodnim i nemogućim. S druge pak strane, prosudio je da nije korisno odavle slati druge snage zbog skupoće pohoda i zbog oskudice tih zemalja. I mudro promislivši pošalje poslanike frangijskom kralju Lodoihu i rimskom papi da priteknu u pomoć ovdašnjim snagama te zajedno s njima zarate na Agarene koji su se nastanili u Bariju, zapovijedivši da se i malo prije spomenute sklavenske zemlje prihvate posla, da Dalmati prijeđu pučinu pomoću stanovnika Rausija i njihovih domaćih plovila. Kad su se oni svi sjedinili, okupi se velika vojska, i kako se rimski zapovjednik nad svima veoma isticao mudrošću i hrabrošću, Bari je brzo osvojen. Sam kastrum, okolno područje i svi zarobljenici vrate se natrag pod rimsku vlast, i zemlja primi vlastite stanovnike, a Soldana i agarenski puk pod njegovim zapovjedništvom uzme frangijski kralj i odvede u Kapiju; on je naime još uvijek vladao tim gradom, kao i Benevendom. I tako završi carev prvi ratni pohod na zapad, i carujući grad bi ukrašen tamošnjim plijenom i slavom."

Ako usporedimo taj dio izvješća u svim trima spisima, primijetit ćemo kako, za razliku od De them. i De adm. imp., pisac Vita Bas. u središte pozornosti prilikom opisa tih događaja ustrajno stavlja Bazilija, koristeći pripovjednu tehniku kojom početak i kraj izlaganja uokviruje Porfirogenetovim djedom. Drugim riječima, podloga priče u svim se trima izvješćima podudara u stvarnim elementima kako je car, nakon što je doznao da su Arapi poharali jug Italije, poslao svoju vojsku, zamolivši pritom franačkog kralja Ludovika II. i papu da mu pomognu, uz čiju je pomoć uspio poraziti Saracene i vratiti Bari pod vlast Bizantskog carstva, no u opisu koji nam donosi autor carske biografije Bazilije dominira kao centralna figura cjelokupnog zbivanja. 
Pritom od figura iskaza zapažamo jednu adjunkciju, ${ }^{105}$ dva hiperbata, ${ }^{106}$ dva homeoteleuta, ${ }^{107}$ jedan izokolon, ${ }^{108}$ jednu sinonimiju ${ }^{109}$ te jednu zeugmu, ${ }^{110}$ od figura mišljenja dva hijazma, ${ }^{111}$ a od tropa jednu metaforu. ${ }^{11}$

Pripovjedač izlaganje počinje time kako je Bazilije silno uznemiren i ne može spavati od briga, tražeći način kako potisnuti neprijatelja s italskog tla. Jačina Bazilijeve želje da pokori neprijatelja izražena je

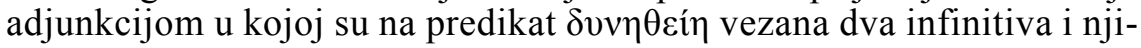
hovi pripadajući objekti, koji su poredani takvim redoslijedom da se

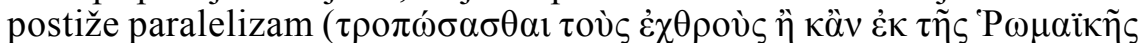

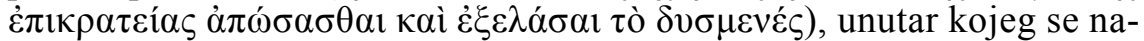

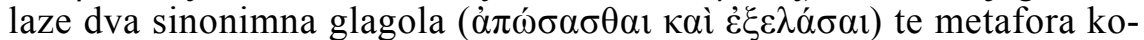

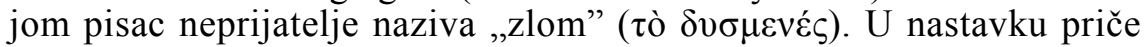
nalazimo detalje kojih nema u De them. i De adm. imp.; razlog Bazilijeva traženja pomoći od franačkoga kralja Ludovika i pape, prema riječima autora Vita Bas., bio bi taj što je car procijenio da brodovlje koje je poslao s Niketom Oorifom nije doraslo za borbu s tolikim neprijateljem, a pojačanje nije htio poslati jer bi to prouzročilo dodatne troškove. Takvo Konstantinovo opširno obrazloženje potrebe da se stvori savez očito mora biti njegovo domišljanje jer konkretnih podataka nema, a u prilog tomu govori i njihovo izostavljanje u De them. i De adm. imp. Tvorac Bazilijeve biografije zasigurno nije htio da se o njegovu djedu stvori slika nesposobna vojskovođe, pa je smatrao potrebnim opravdati Bazilijev poziv u pomoć. Nastavak se akcije u potpunosti podudara $\mathrm{s}$ De adm. imp., jer se navodi kako je car naredio slavenskim plemenima da se pridruže pohodu te kako su ih na drugu jadransku obalu prevezli stanovnici Raguze na svojim plovilima (ovih podataka nema u $D e$ them.). Vijest o tome kako je Soldana i saracensku vojsku franački kralj sa sobom odveo u Kapuu iskazana je homeoteleutom ( $\tau$ òv $\delta \varepsilon \dot{\varepsilon} \Sigma o \lambda \delta \alpha ́ v o v$

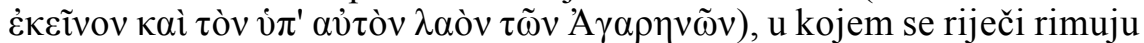
u tolikoj mjeri da je postignut i ritmički efekt. Pritom je samo Ludovikovo ime očito namjerno ispušteno, kako se time ne bi umanjio značaj Bazilijeve uloge u intervenciji, a čitateljeva je pozornost već u sljedećoj

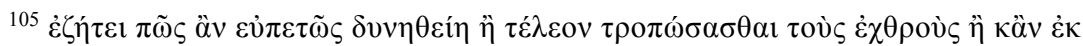

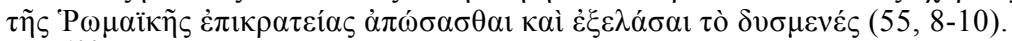

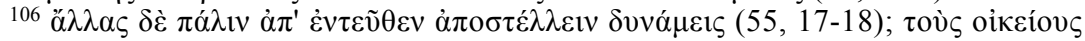

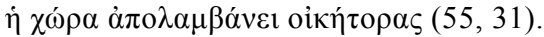

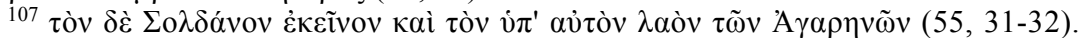

Drugi se homeoteleut nalazi u primjeru s izokolonom.

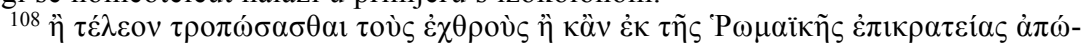

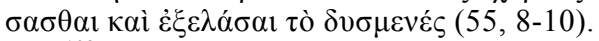

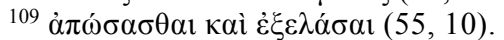

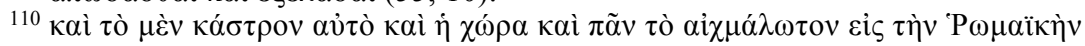

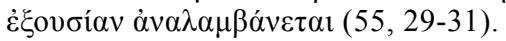

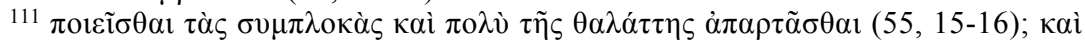

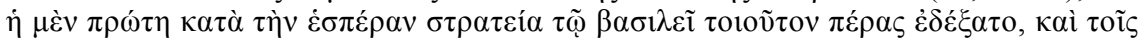

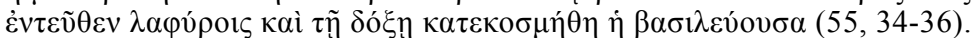

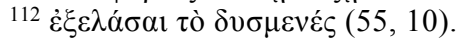


rečenici ponovno skrenuta na Porfirogenetova djeda, gdje pripovjedač priču završava rečenicom o tome kako je Bazilijev prvi ratni pohod na zapadu završio uspješno, a Konstantinopol bio ukrašen slavom i ratnim plijenom iz tih krajeva.

Pripovijest o pohodu Saracena zaključena je, dakle, u svim trima knjigama viješću kako je Soldan zajedno sa svojom vojskom odveden u zarobljeništvo i tvrdnjom o bizantskom suverenitetu u južnoj Italiji. Međutim, nastavak te priče nalazimo u De adm. imp. i Vita Bas., gdje su prikazani dalji doživljaji Soldana i Ludovika II. ${ }^{13}$ Pripovjedač je u tim dvama djelima nakon opisa podjele plijena, po kojoj je Bazilije uzeo teritorij, a Ludovik zarobljenike, među kojima i Soldana, i odveo ih u Kapuu i Benevent, spomenom tih dvaju gradova uveo novi sadržaj, u kojem baš oni igraju jednu od glavnih uloga i čijim dolaskom pod bizantsko zapovjedništvo završava dio o bizantskoj intervenciji u južnoj Italiji, uklopivši na istom mjestu anegdotu o tome kako Soldana nitko nikad nije vidio kako se smije. ${ }^{114}$ Zanimljivo je, kako je to već uočeno u komentarima ${ }^{115}$ da je pripovijest o robu koji se nikad ne smije u $D e$ adm. imp. uvrštena nespretno, bez pripreme ili novog retka, te je vidljiv procjep u šavu: premda se, osim Soldana, $u$ istoj rečenici spominju car Bazilije i kralj Ludovik, u prvoj rečenici anegdote upotrijebljena je pokazna zamjenica u jednini koja bi se mogla odnositi na bilo koga od njih. ${ }^{116}$ Tek iz daljeg teksta vidljivo je kako je riječ o Soldanu. U Vita Bas. pisac je dodavanje novog izvora izveo mnogo vještije. Nespretni je hijat popunio osobnim komentarom te time upozorio čitatelja da je riječ o anegdoti. ${ }^{117}$

\section{Zaključak}

Međusobna usporedba priče o saracenskom pohodu na Dalmaciju i južnu Italiju u Vita Bas., De adm. imp. i De them. s gledišta upotrebe stilskih sredstava urodila je spoznajom kako je car-pisac neminovno

${ }^{113}$ De adm. imp., 29, 119-216; Vita Bas., 56-59.

${ }^{114}$ De adm. imp., 29, 119-127; Vita Bas., 56.

115 Porphyrogenitus, Commentary, 101-102.

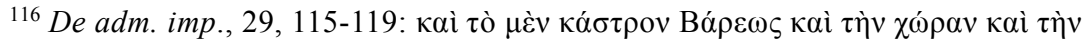

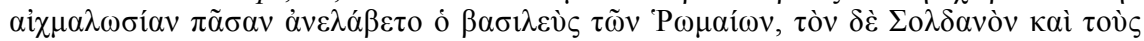

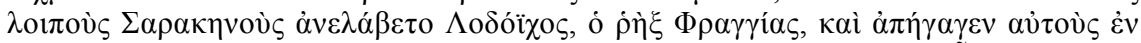

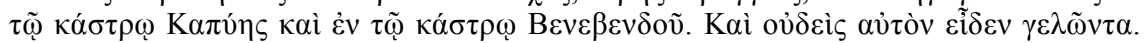
„Kastrum Bari, zemlju i sve zaplijenjeno uzme rimski car, a Soldana i ostale Sarakene uzme frangijski kralj Lodoih te ih odvede u kastrum Kapiju i u kastrum Benevend. I nitko ga ne vidje nasmijana."

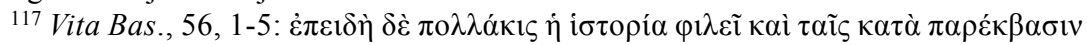

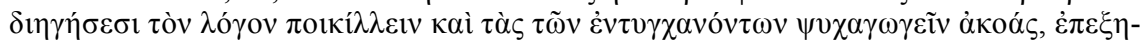

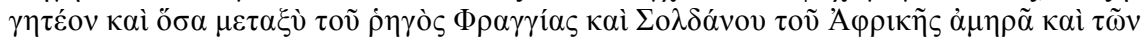

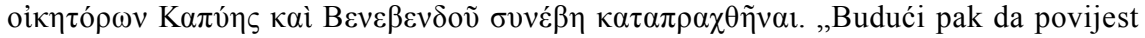
često voli govor prošarati uzgrednim razlaganjima i zabavljati uši slušatelja, valja izložiti i što se zbilo između frangijskoga kralja, afričkog emira Soldana i stanovnika Kapije i Benevenda." 
izvještaj crpio iz istog vrela, koji je činio dio njegove zbirke dokumenata iz carskog arhiva, ali ga je prilagodio u skladu s tematikom djela tako da je ili dinamizirao upotrebu ukrasnih stilskih sredstava, obogativši na taj način i podigavši njegov stilski izričaj na višu razinu, ili je ograničenom upotrebom ornatusa postigao nešto manji odmak od nulte točke stilskog iskaza. Izvješće se u svim trima spisima podudara u stvarnim povijesnim elementima i završava konstatacijom o bizantskom suverenitetu u južnoj Italiji, iako ga je autor De adm. imp. i Vita Bas. proširio pričom o doživljajima Soldana i Ludovika II., uklopivši pritom i legendu o Soldanu. U De them., gdje je riječ o pokrajinama unutar carstva, ona se zacijelo nije uklapala mjestom događanja, a to je franački dvor u Italiji. Najviše na svoje izlaganje pazi pripovjedač Bazilijeve biografije, vodeći pritom računa kako o stilu, tako i o povezanosti misli, te o cjelokupnoj unutarnjoj cjelovitosti priče. Svojom literarnom imaginacijom pripovijest o toj važnoj epizodi iz bizantske povijesti pretočio je u književni oblik te je time uskladio sa standardima koje postavlja

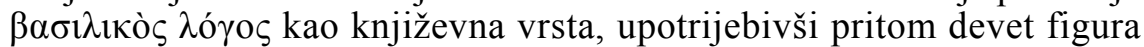
iskaza (adjunkcija, asindeton, hendiadioin, hiperbat, homeoteleut, izokolon, polisindeton, sinonimija, zeugma), šest figura mišljenja (antiteza, gnoma, hijazam, klimaks, parenteza, poredba) i pet tropa (antonomazija, litota, metafora, metonimija, perifraza), po čemu bi ovo izvješće, u odnosu na ostala dva, bilo na najvišoj stilskoj razini. Iako sva tri spisa iskazuju lojalnost Baziliju, treba naglasiti kako se ona u De them. i De adm. imp. doživljava objektivnijom i umjerenijom s pripovjedačeve pozicije, dok je u Vita Bas. nemoguće ne zamijetiti piščevu subjektivnost i autorovu snažnu privrženost svom djedu, koja se zrcali u ustrajnoj tendenciji da se Bazilija prikaže kao glavnog aktera svih zbivanja. Naslućujemo kako ova sklonost izranja iz činjenice da Bazilije nije osobno sudjelovao u toj vojnoj intervenciji, pa se izlagač služi raznim pripovjednim tehnikama ne bi li time uveličao carevu ulogu u opisanom povijesnom događaju, ne samo pripovijedajući o Bazilijevu konkretnom djelovanju, već i ulazeći u karakterizaciju njegova lika opisom njegovih misli i duševnih osjećaja; upravo su iz istog razloga u izvješću izostavljena imena koja bi mogla zasjeniti veličinu Bazilijeve slave, poput onoga Ludovika II. koji je osvojio Bari i zarobio Soldana.

Osim što je najkoncizniji jer ne sadrži priču o tome kako je Soldan prevario Ludovika II., izvještaj u De them. je i stilski najjednostavniji, s pet figura iskaza (etimološka figura, hiperbat, homeoteleut, izokolon,zeugma) i jednom mišljenja (hijazam). Srednje bi mjesto po svojim stilskim karakteristikama pripalo izvješću u De adm. imp., gdje je uočeno šest figura iskaza (etimološka figura, homeoarkt, homeoteleut, izokolon, paronomazija, zeugma), jedna mišljenja (hijazam) i tri tropa (antonomazija, metonimija, perifraza); ograničena upotreba ornatusa ovdje ne iznenađuje, budući da se čitav spis, čije su ambicije povijest i vanjska politika, a ne glorifikacija obiteljskog pretka, temelji na povijesnim izvorima. Sagledamo li upotrebu stilskih sredstava u izvješćima u okvirima istosti ili različitosti njihova autorstva, podatak da se u svim 
trima izvješćima od figura iskaza najčešće javljaju hiperbat, homeoteleut, izokolon i zeugma, od figura mišljenja hijazam, a od tropa antonomazija, metonimija i perifraza u De adm. imp. i Vita Bas., ukazivao bi na neosporno postojanje zajedničkih stilskih značajki kao i na to da, unatoč tomu što u Vita Bas. nalazimo daleko najveći broj upotrijebljenih stilskih ukrasa (što je, uostalom, očekivano ako imamo na umu da se radi o pohvalnom govoru), a u De adm. imp. i De them. osjetno manji, po čemu bi ova dva spisa međusobno bila najbliža, stilske razlike među izvješćima nisu tako značajne da bi nužno upućivale na različite autore te bi isti autor mogao varirati svoj stil. Zaključimo, dakle, kako su nejednake stilske razine izvještaja o pohodu Saracena u tim Porfirogenetovim djelima posljedica njihove pripadnosti različitim književnim vrstama i njihovim različitim tematikama. Autor odnosno redaktor tih spisa intervenirao je u predložak u onolikoj mjeri, koliko mu je omogućio sadržaj građe, uloživši pritom svoj najveći trud pri podizanju stilskog naboja u izvješće u djedovu životopisu, a osjetno manji u spisima diplomatsko-dokumentarnog karaktera De them. i De adm. imp.

\section{LITERATURA}

Bagić, Krešimir. Rječnik stilskih figura. Zagreb: Školska knjga, 2012.

Bury, John B. "Rasprava De administrando imperio". Preveo Šandor Lochmer. Vjestnik Kraljevskog hrvatsko-slavonsko-dalmatinskog arkiva 10 (1908), 91-144. Izvorni engleski tekst Bury, John B. "The treatise De administrando imperio." Byzantinische Zeitschrift 15, 517-577.

Bury, John B. A History of the Eastern Roman Empire. London: Macmillan and co., 1912.

Denniston, John D. Greek Prose Style. Oxford: Clarendon Press, 1952.

Dover, Kenneth J. Greek Word Order. Cambridge: University Press, 1960.

Ferjančić, Božidar, ur. Vizantiski izvori za istoriju naroda Jugoslavije, tom II. Beograd: Naučna knjiga, 1959.

Hirsch, Ferdinand. Byzantinische Studien. Leipzig: Verlag von S. Hirzel, 1876.

Jenkins, Romilly J. H. "Constantine VII's Portrait of Michael III". Bulletin de la Classe des lettres et des sciences morales et politiques, Académie Royale de Belgique (5e Série) 34 (1948), 71-77. Pretisak u Jenkins, Romilly J. H. Studies on Byzantine History of the Ninth and Tenth Centuries, no. 1. London: Variorum, 1970.

Lausberg, Heinrich. Handbook of Literary Rhetoric: A Foundation for Literary Study. Edited by David E. Orton and R. Dean Anderson. Leiden-Boston-Köln: Brill, 1998.

Lončar, Milenko. "Filološka analiza Porfirogenetovih vijesti o Hrvatima". Doktorska disertacija, Filozofski fakultet u Zadru Sveučilišta u Splitu, 2002.

Lončar, Milenko. "Dalmatinske etimologije Konstantina Porfirogeneta". Folia onomastica Croatica 11 (2002), 149-174.

Manojlović, Gavro. "Jadransko pomorje IX. stoljeća u svjetlu istočno-rimske (bizantinske) povijesti”, Rad JAZU 150 (1902), 1-102.

Margetić, Lujo. "Bilješke u vezi s nastankom hrvatske države u 9. stoljeću". U: Etnogeneza Hrvata, uredio Neven Budak, 144-147. Zagreb: Nakladni zavod Matice 
Hrvatske i Zavod za hrvatsku povijest Filozofskog fakulteta Sveučilišta u Zagrebu, 1995.

Mommsen, Tycho. Beiträge zu der Lehre von den griechischen Präpositionen. Berlin: Weidmannsche Buchhandlung, 1895.

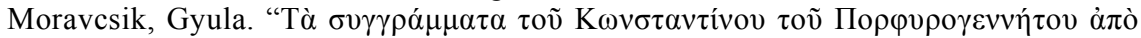
$\gamma \lambda \omega \sigma \sigma \iota \kappa \tilde{\varsigma} \varsigma \dot{\alpha} \pi$ ó $\psi \varepsilon \omega \varsigma$ ”. U: Atti del 5 Congresso internazionale di studi bizantini, Roma 20.-26. settembre 1936., 514-520. Roma: Tipografia del Senato del dott. G. Bardi, 1939.

Ostrogorski, Georgije. Povijest Bizanta 324.-1453.. Preveli Marina Miladinov i Kiril Miladinov. Zagreb: Golden marketing, 2002.

Porphyrogenitus, Constantine. De administrando imperio. Edited by Gyula Moravcsik, translated by Romilly J. H. Jenkins. Washington: Dumbarton Oaks, 1967.

Porphyrogenitus, Constantine. De administrando imperio. A Commentary. Edited by Romilly J. H. Jenkins et al. London: University of London, 1962.

Porfirogenito, Costantino. De thematibus. Introduzione, testo critico, commento a cura di Andrea Pertusi. Città del Vaticano: Biblioteca Apostolica Vaticana, 1952.

Serreqi Jurić, Teuta. "Usporedba jezično-stilskih osobitosti Porfirogenetovih djela Vita Basilii i De thematibus". Doktorska disertacija, Sveučilište u Zagrebu, 2016.

Ševčenko, Ihor, ed. Chronographiae quae Theophanis Continuati nomine fertur liber quo vita Basilii imperatoris amplectitur. Berlin-Boston: De Gruyter, 2011.

Ševčenko, Ihor. "Re-reading Constantine Porphyrogenitus". U: Byzantine Diplomacy: Papers from the Twenty-Fourth Spring Symposium of Byzantine Studies, Cambridge, March 1990, edited by Jonathan Shepard and Simon Franklin, 167-195. Aldershot: Variorum, 1992.

Šišić, Ferdo. Povijest Hrvata u vrijeme narodnih vladara. Zagreb: Nakladni zavod Matice hrvatske, 1990. Pretisak izdanja iz 1925.

Švab, Mladen, ur.; Tomašić, Nikola, prev. Konstantin Porfirogenet. O upravljanju carstvom. Zagreb: August Cesarec, 1994.

Tartaglia, Luigi. "Livelli stilistici in Constantino Porfirogenito". Jahrbuch der Österreichischen Byzantinistik 32 (1982), br. 2: 197-206.

\section{SUMMARY}

\section{STYLISTIC VARIATIONS IN PORPHYROGENITUS' ACCOUNTS OF THE SARACEN CONQUEST OF DALMATIA AND SOUTHERN ITALY}

A historical account of the Saracen conquest of Dalmatia and Southern Italy (866-867) is found in three of Porphyrogenitus' prose works - Vita Bas. $(53,55)$, De them. (II, 11, 18-44) and De adm. imp. (29, 88-119). The accounts are embedded into the chapters which describe the history of Southern Italy and Dalmatia, and their mutual connection is explained by the existence of a common source which has been lost. The aim of this paper is to illustrate stylistic differences in the accounts by comparing them and analyzing their use of stylistic devices and other stylistic characteristics which mark the author's stylistic expression, as well as to present how the same report is able to achieve a different expressive dimension depending on the genre characteristics of the work and the use of rhetorical devices related to it. The research has shown that the author obtained his information from the same source, which formed part of a collection of documents from the imperial archive, judging by the fact that all three accounts coincide in the actual historical details; the author of Vita 
Bas. and De adm. imp, however, continued the story by relating the adventures of Soldan and Lewis II. Additionally, unequal stylistic levels of the reports in these three works are a consequence of their different literary genres and themes, due to the fact that editor of the text intervened in the template as much as the content of the work allowed. The greatest effort to achieve an exalted stylistic expression was made by the author of Basil's biography; using his literary imagination, he altered the story of this important episode from Byzantine history into a literary form, and adjusted it with the genre standards of $\beta \alpha \sigma \imath \lambda \iota \kappa o ̀ \varsigma ~ \lambda o ́ \gamma o \zeta$ by applying nine figures of speech, six figures of thought, and five tropes. On the other hand, in the accounts of the diplomatic and documentary texts De them. and De adm. imp. a much lower level of style is noticed. The simplest from a stylistic point of view is the account in De them., with five figures of speech and one figure of thought, while the report in $D e$ $a d m$. imp. is a bit more polished, with six figures of speech, one figure of thought, and three tropes. Despite the fact that the largest number of stylistic devices by far is present in Vita Bas., being noticeably scarcer in De them. and De adm. imp. (making these two texts the most similar of the three), the presence of common stylistic features cannot be denied, as reflected in the fact that in all of the accounts the most frequent stylistic devices are hyperbaton, homoeoteleuton, isocolon and zeugma as figures of speech, chiasmus as a figure of thought, and the tropes antonomasia, metonymy and periphrasis in Vita Bas. and De adm. imp. Consequently, we can assume that the stylistic differences between these accounts are not so significant that they would inevitably indicate that their authors are different, but rather that, in this case, the same author varied his style.

Key words: Vita Basilii; De thematibus; De administrando imperio; Basil I; Saracens; Bari; Dalmatia; stylistic devices 
